\title{
Arachidonic Acid Metabolism and Kidney Inflammation
}

\author{
Tianqi Wang ${ }^{1,2,+}$, Xianjun Fu ${ }^{2,3,+}$, Qingfa Chen ${ }^{4} \oplus^{\circ}$, Jayanta Kumar Patra ${ }^{5}{ }^{\oplus}$, Dongdong Wang ${ }^{6,7}{ }^{\circ}$, \\ Zhenguo Wang ${ }^{2, *}$ and Zhibo Gai ${ }^{3, *}$ \\ 1 Traditional Chinese Medicine History and Literature, Institute for Literature and Culture of Chinese \\ Medicine, Shandong University of Traditional Chinese Medicine, Jinan 250355, China \\ 2 Institute for Literature and Culture of Chinese Medicine, Shandong University of Traditional Chinese \\ Medicine, Jinan 250355, China \\ 3 Key Laboratory of Traditional Chinese Medicine for Classical Theory, Ministry of Education, \\ Shandong University of Traditional Chinese Medicine, Jinan 250355, China \\ 4 The Institute for Tissue Engineering and Regenerative Medicine, The Liaocheng University, \\ Liaocheng 252000, China \\ 5 Research Institute of Biotechnology \& Medical Converged Science, Dongguk University-Seoul, \\ Goyangsi 10326, Korea \\ 6 Institute of Clinical Chemistry, University Hospital Zurich, University of Zurich, Wagistrasse 14, \\ 8952 Schlieren, Switzerland \\ 7 Guizhou University of Traditional Chinese Medicine, Fei Shan Jie 32, Guiyang 550003, China \\ * Correspondence: zhenguow@126.com (Z.W.); zhibo.gai@usz.ch (Z.G.); Tel.: +86-13505312372 (Z.W.); \\ +41-43-253-2068 (Z.G.) \\ + These authors contributed equally to this work.
}

Received: 8 July 2019; Accepted: 20 July 2019; Published: 27 July 2019

\begin{abstract}
As a major component of cell membrane lipids, Arachidonic acid (AA), being a major component of the cell membrane lipid content, is mainly metabolized by three kinds of enzymes: cyclooxygenase (COX), lipoxygenase (LOX), and cytochrome P450 (CYP450) enzymes. Based on these three metabolic pathways, AA could be converted into various metabolites that trigger different inflammatory responses. In the kidney, prostaglandins (PG), thromboxane (Tx), leukotrienes (LTs) and hydroxyeicosatetraenoic acids (HETEs) are the major metabolites generated from AA. An increased level of prostaglandins (PGs), $\mathrm{TxA}_{2}$ and leukotriene $\mathrm{B} 4\left(\mathrm{LTB}_{4}\right)$ results in inflammatory damage to the kidney. Moreover, the $\mathrm{LTB}_{4}$-leukotriene $\mathrm{B} 4$ receptor 1 (BLT1) axis participates in the acute kidney injury via mediating the recruitment of renal neutrophils. In addition, AA can regulate renal ion transport through 19-hydroxystilbenetetraenoic acid (19-HETE) and 20-HETE, both of which are produced by cytochrome P450 monooxygenase. Epoxyeicosatrienoic acids (EETs) generated by the CYP450 enzyme also plays a paramount role in the kidney damage during the inflammation process. For example, 14 and 15-EET mitigated ischemia/reperfusion-caused renal tubular epithelial cell damage. Many drug candidates that target the AA metabolism pathways are being developed to treat kidney inflammation. These observations support an extraordinary interest in a wide range of studies on drug interventions aiming to control AA metabolism and kidney inflammation.
\end{abstract}

Keywords: arachidonic acid; cyclooxygenase; lipoxygenase; cytochrome P450; kidney inflammation; therapeutic target

\section{Introduction}

Arachidonic acid (AA), also named eicosa-5,8,11,14-tetraenoic acid, is a $\omega-6$ polyunsaturated fatty acid (PFA) and is mainly present in the form of phospholipids in the cell membrane. When cells are under stress, $\mathrm{AA}$ is released from the phospholipids by phospholipase $\mathrm{A}_{2}\left(\mathrm{PLA}_{2}\right)$ and phospholipase $\mathrm{C}$ (PLC) as free arachidonic acids [1-3], which become the precursor of proinflammatory bioactive 
mediators through three metabolic pathways. Through the cyclooxygenase (COX) pathway, AA can be metabolized into prostaglandins (PGs) and thromboxanes (TXs). AA can also be converted into leukotrienes (LTs) and lipoxins (LXs) by the lipoxygenase (LOX) pathway [4-6]. Moreover, AA also generates epoxyeicosatrienoic acids (EETs) or hydroxyeicosatetraenoic acids (HETEs) through the cytochrome P450 (CYP450) pathway. Together, these AA metabolites are referred as eicosanoids, which are effective autocrine and paracrine bioactive mediators, and are widely involved in a variety of physiological and pathological processes [7-10].

Kidney inflammation, characterized by hematuria, proteinuria, edema, hypertension, etc., is caused by immune-mediated inflammatory mediators (such as complement, cytokines, reactive oxygen species, etc.), resulting in a group of kidney diseases with a varying degree of renal dysfunction. Without prompt treatment, it will lead to thromboembolism, acute renal failure (and even chronic nephritis), chronic renal failure and finally uremia [11].

The relationship between AA and inflammation attracts our interest in the effect of AA metabolism on kidney inflammation. Therefore, we systematically summarized the effect of AA-derived bioactive mediators on kidney inflammation by discussing the regulatory mechanism of AA metabolism in the kidney, followed by the mechanism of AA-induced renal inflammation and a potential treatment targeting the AA metabolism.

\section{Regulation of the AA Metabolism in the Kidney}

\subsection{The Release of $A A$}

Normally, AA exists in the cell membrane in the form of phospholipids. When the cell membrane is subjected to stimuli, especially the inflammatory reaction, the phospholipids are released from the cell membrane. Through the hydrolysis of phospholipids by PLA 2 and PLC $[1,3,12]$, AA is released and then transformed into a bioactive metabolite with the help of different enzymes, thus promoting inflammatory cascades. At present, it is well known that at least three metabolic pathways (the COX pathway, LOX pathway and CYP450 pathway) are involved in the metabolism of AA, which are closely related to the occurrence, development, and regression of renal inflammation (Figure 1) [1].

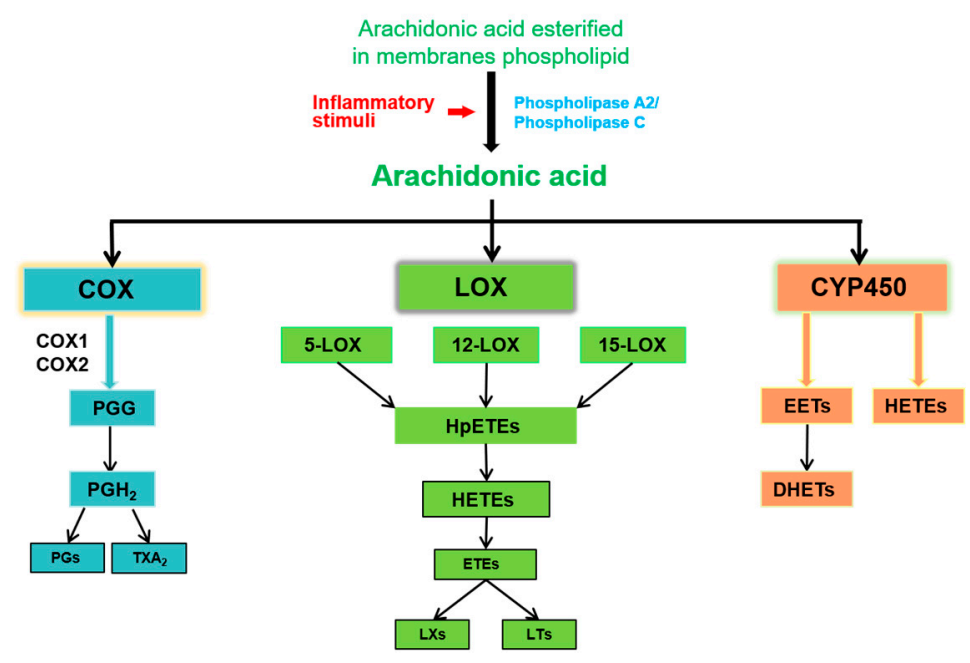

Figure 1. Scheme of eicosanoids biosynthesis pathways from arachidonic acid.

\subsection{COX Pathway}

COX-1/2, also called prostaglandin H synthase (PGHS), is one of the key enzymes involved in the AA metabolism [13]. The constitutive enzyme COX-1 is responsible for the expression of prostaglandin $\mathrm{E}_{2}\left(\mathrm{PGE}_{2}\right)$ at the background level or the expression of PG under hypotonic swelling stimulation [14]. COX-2 is almost not expressed at normal physiological conditions; however, it is highly expressed when the kidney is under the influence of stimuli, such as chronic sodium deficiency and ultrafiltration [15]. 
It is important to note that COX-2 is the dominating source of prostacyclin [16]. Once AA is released, it can be metabolized by two isozymes of PGHS, PGHS-1 and PGHS-2 [17]. PGHSs have two different but complementary enzyme activities, one is cyclooxygenase (dioxygenase) activity, which catalyzes the production of $\mathrm{PGG}_{2}$ from arachidonic acid, and the other is peroxidase activity, which promotes the reduction of $\mathrm{PGG}_{2}$ to $\mathrm{PGH}_{2}$ [18]. In general, the COX protein contains a cyclooxygenase site and a peroxidase site. AA is converted to the endogenous hydrogen peroxide $\mathrm{PGG}_{2}$ by the cyclooxygenase site, and the peroxidase site is responsible for reducing $\mathrm{PGG}_{2}$ to $\mathrm{PGH}_{2}$ [19]. COXs initially metabolize AA to unstable $\mathrm{PGG}_{2}$ by their $\mathrm{COX}$ function and then convert it to $\mathrm{PGH}_{2}$ by their peroxidase function. $\mathrm{PGH}_{2}$, like cell-and tissue-selective prostanoid synthases and isomerases, is not stable, and can easily generate many bioactive prostaglandins, such as prostaglandins D2, E2, F2 $\alpha$, and $\mathrm{I}_{2}$, and TXA , depending on the differential expression of these synthetases in different tissues [20-23]. $\mathrm{PGH}_{2}$ can also be decomposed into malonaldehyde (MDA) and 12L-hydroxy-5,8,10-heptadecatrienoic acid (HHT) by thromboxane synthase [24]. The process of converting $\mathrm{PGH}_{2}$ to $\mathrm{PGD}$ requires two PGD synthetases, namely hematopoietic PGD synthase (H-PGDS) and lipocalin-type PGD synthase (L-PGDS). Then the $\mathrm{PGD}_{2}$ is metabolized to 15 -deoxy- $\Delta$ 12,14-prostaglandin J 2 (15d-PGJ 2) [25]. $\mathrm{PGI}_{2}$ is extremely unstable, with a half-life of only two to three minutes, and is easily converted to 6-keto-prostaglandin $\mathrm{F} 1 \alpha$ spontaneously [26,27]. In particular, $\mathrm{PGH}_{2}$ is produced in most cells by the action of microsomal $\mathrm{PGE}_{2}$ synthase (mPGES). $\mathrm{PGE}_{2}$ is synthesized in almost all human cells and exerts extremely complex physiological effects in the inflammatory response through the signaling pathway which is composed of four G protein-coupled receptors: E-type prostanoid receptors (EP)1, EP2, EP3 and EP4 [28-30]. As for $\mathrm{TXA}_{2}$, AA can generate TXA 2 via the action of thromboxane synthase [31], which has a half-life of only about $30 \mathrm{~s}$ and is then spontaneously converted to thromboxane $\mathrm{B}_{2}\left(\mathrm{TXB}_{2}\right)[32,33]$. Three things that need to be especially pointed out are that platelets mainly form TXA $A_{2}$, endothelial cells mainly form $\mathrm{PGI}_{2}$, and $\mathrm{PGE}_{2}$ is the main prostatic body produced by renal collecting tubule cells [34]. In recent years, another variant of the COX family, COX-3 (or CX-1b), which is an allosteric splice variant of COX-1, has been discovered, and its gene sequence differs from COX-2 in such a way that the COX-3 retains the intron 1 sequences [35]. COX-3 also catalyzes the production of $\mathrm{PGH}_{2}$, its activity can be inhibited by crude aminophenol, and it is mainly expressed in the microvessels of the brain and heart [36-38]. Hence, its role in AA metabolism and kidney inflammation needs to be further explored.

\subsection{LOX Pathway}

Under the catalysis of lipoxygenase, AA is metabolized into hydroperoxyeicosatetraenoic acid (HpETE). Current research suggests that at least four enzymes, namely 5-LOX, 8-LOX, 12-LOX, and 15-LOX are involved in the metabolism of AA in the LOX pathway. However, the 5-, 12-, and 15-positions are the main oxidation sites of $\mathrm{AA}$, leading to oxidation reactions that are based on the catalysis of 5-LOX, 12-LOX, and 15-LOX enzymes. In this review, we focus on the 5-LOX, 12-LOX and 15-LOX pathways (Figure 2).

Human 5-LOX holds a major function in kidney inflammation, ranging from kidney tubules to glomeruli. In this pathway, AA forms 5-hydroperoxyeicosatetraenoic acid (5-HpETE) by dioxygenase [39], and then $95 \%$ is generated into 5-hydroxyeicosatetraenoic acid (5-hydroxy-6,8,11,15-eicosatetraenoic acid, 5-HETE) at C7 and 5\% is generated into 8-HETE at C10, which are the first two steps during the conversion process of AA to proinflammatory LTs [40]. Besides, Oxo-ETE is generated via the LOX product, HETEs by the microsomal dehydrogenase in the human polymorphonuclear leukocytes (PMNLs) [39,41]. Then, oxo-ETEs are formed through the oxidation of HETEs [42,43], which is the strongest eosinophil chemoattractant among bioactive mediators. From here, AA metabolites are further converted to $\mathrm{LTA}_{4}$ and LXs via 5-LOX activator protein (5-FLAP) and dehydrase [44]. Basically, the catalytic function of the 5-LOX enzyme is mainly manifested in the following two aspects: one is the insertion of molecular oxygen by dioxygenase activity and the other is the formation of epoxide by $\mathrm{LTA}_{4}$ synthase activity. Regarding 5-HpETE, it is generated from AA through homolytic cleavage and removal of hydrogen on the pro-S hydrogen at carbon-7 [39]. 5-LOX can generate $\mathrm{LTA}_{4}$ by removing 
the $\mathrm{C} 10$ hydrogen atom from 5-HpETE [45]. $\mathrm{LTA}_{4}$ is unstable and can be hydrolyzed or combined with glutathione or transcellularly transferred to generate bioactive eicosanoids. In neutrophils and other inflammatory cells of kidney tissue, $\mathrm{LTA}_{4}$ is catalyzed by epoxide hydrolase to form $\mathrm{LTB}_{4}$ [46]. $\mathrm{LTA}_{4}$ and glutathione (GSH) catalyze the production of $\mathrm{LTC}_{4}$ using glutathione S-transferase (GST) and then remove glutamic acid to form $\mathrm{LTD}_{4}$ via $\gamma$-glutamyl transferase, which is further metabolized by dipeptidase to form $\mathrm{LTE}_{4}$. Then, $\mathrm{LTF}_{4}$ is synthesized from LTE 4 by $\gamma$-glutamyl transferase [47].

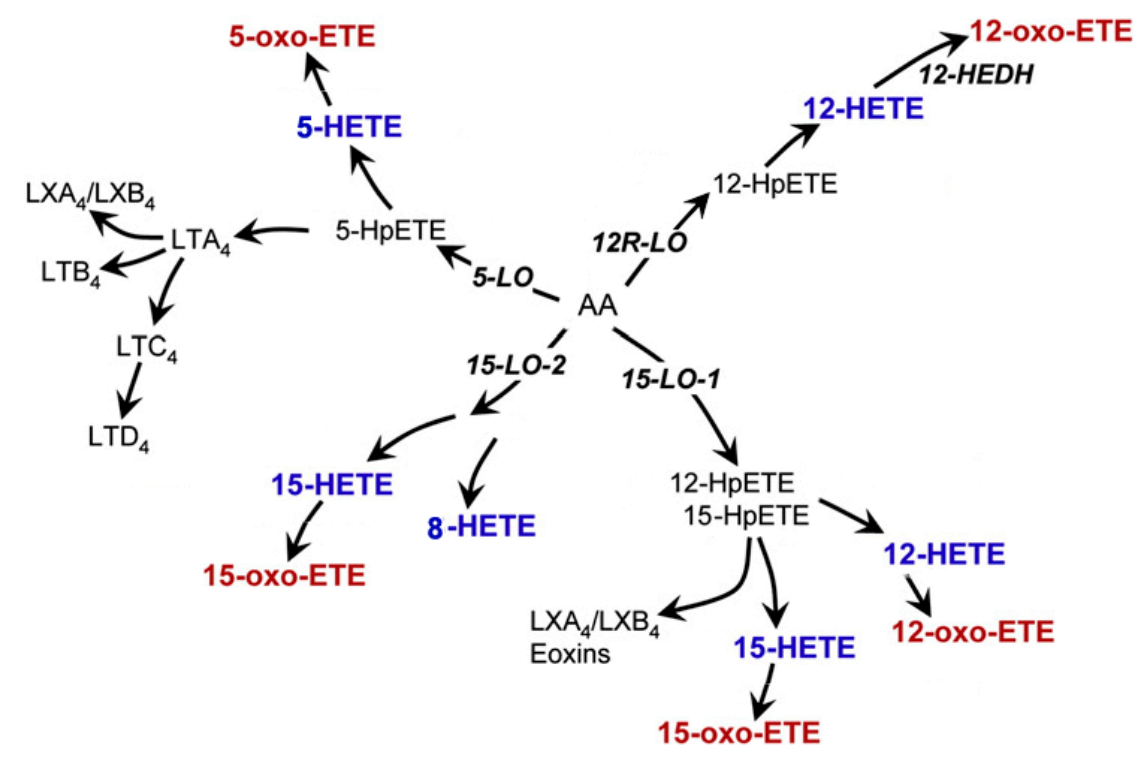

Figure 2. Lipoxygenase, and dehydrogenase pathways for the formation of HETEs, oxo-ETEs, and related eicosanoids.

The roles of the 12-LOX and 15-LOX pathways are mainly in the production of HETEs and LXs. The 12-LOX pathway is similar to the 5-LOX pathway. AA first generates 12-HpETE and 12-hydroxyeicosatetraenoic acid (12-HETE) via 12-LOX [48,49]. But there is a difference between them, as in addition to the conversion of AA to 12-HETE, 12-LOX can also convert 5(S)-HETE to 5(S),12(S)-dihydroxyeicosatetraenoic acid (-diHETE) as well as metabolize 15(S)-HETE to 14(R),15(S)-diHETE in the leukocytes. These products ultimately convert into extra-platelet $\mathrm{LTA}_{4}[50,51]$. Another biosynthetic pathway for LXs involves 5-LOX in neutrophils and 12-LOX in the platelets. 5-LOX generates $\mathrm{LTA}_{4}$ in the neutrophil, which is then transferred to the platelet, where 12-LOX subsequently generates either $\mathrm{LXA}_{4}$ or $\mathrm{LXB}_{4}[45,52,53]$. Same as the 12-LOX pathway, the principal effect of the 15-LOX pathway is to ultimately generate HETEs, ETEs and LXs. There are two isoforms in mammalian cells: 15-LOX-1 and 15-LOX-2. 15-LOX-1 (12/15-LOX), which is encoded by the arachidonate 15-lipoxygenase (ALOX15) gene, could metabolize AA into $\mathrm{LXA}_{4}, \mathrm{LXB}_{4}$ and 15-oxo-ETEs [43,45], while 15-LOX-2 will metabolize AA into 15-oxo-ETE and 8SHETE. HpETEs. In particular, when using 5, 15-diHpETE as a substrate, the primary product catalyzed by 12-LOX and 15-LOX-1 is $\mathrm{LXB}_{4}$, and the efficiency of 15-LOX-1 is 20 times higher than that of 12-LOX [45]. In humans, 15-LOX-1 and leukocyte 12-LOX have high homology and can form 12(S)-HETE and 15(S)-HETE simultaneously, so these two pathways can be collectively called 12/15-LOX (12/15-LOX). When 15-LOX-2 metabolizes AA to produce only 15-HETE, 15-LOX-1 also metabolizes linoleic acid to synthesize hydroxyoctadecadienoic acid [54]. Then, 15-HETE is rapidly converted into $\mathrm{LXA}_{4}$ or $\mathrm{LXB}_{4}$ by hydrolase [55].

\subsection{Cytochrome P450 (CYP450) Pathway}

The CYP450 pathway is the major metabolic pathway of AA in the kidney [56]. CYP450 can be detected in the endoplasmic reticulum, mitochondria and nuclear membrane of the kidney [57,58]. In general, AA produces corresponding metabolites mainly through three kinds of reduced triphosphopyridine nucleotide (NADPH, or reduced coenzyme II)-dependent oxidation in the CYP450 pathway. The first is the 
formation of 5,6-; 8,9-; 11,12-; and 14,15-epoxyeicosatrienoic acids (EETs) through surface oxidation [59-63]. The kidney is an organ with high expoxygenase activity, which, like the liver, also produces enantioselective EETs. In the case of lipoxygenase and cyclooxygenase, AA is first converted to hydrogen peroxide (HpETEs) [43], and then through CYP450 isozymes, oxo-ETEs can also be formed directly from HpETEs (just like the common process of forming HETEs via enzymatic oxidation) [42]. 14,15-EET is the main epoxy compound formed by kidney, and most of the isomers in this region are in $(\mathrm{R}, \mathrm{S})$ configuration. CYP2 is the main CYP450 epoxygenase family, and more importantly, CYP2C8 is the most paramount and plays a central epoxygenase role in the metabolism of AA to biologically active EETs in human kidney $[64,65]$. In addition, the CYP2J family also contributes to the formation of EETs in human and mouse kidneys $[64,65]$. Early research of CYP2C epoxygenases suggested that CYP2C29 and CYP2C39 produced 14,15-EET, and the CYP2C38 produced 11,12-EET [66]. In particularly, human CYP2J2 isoforms are extremely efficient at epoxidation of AA at the 14,15-position [67]. CYP2J5 is an epoxygenase enzyme that is confined in tubular cells and metabolizes AA to 8,9-EET; 11,12-EET; and 14,15-EET in the mouse kidney [68]. Therefore, different vascular smooth muscle cells and epithelial transport processes controlled by EETs have led to the differential localization and regulation of renal vascular and tubular CYP450 cyclooxygenase, and these conclusions are consistent throughout [69]. Then, EETs are mainly hydrolyzed by soluble epoxide hydrolase (sEH) to form 5,6-; 8,9-; 11,12-; and 14,15-dihydroxyepoxyeicosatrienoic acids (DHETs), which possess weak biological activity [70]. Recent research has confirmed that $\mathrm{SEH}$ is one of the key enzymes in the metabolism of EETs, and the regulation of sEH activity and can change the level of EETs in vivo [70].

The other two CYP450 pathways ultimately produce HETEs. One is the formation of 5-, 8-, 9-, 11-, $12-$, or 15-HETEs by propylene oxidation. HpETEs produced by lipoxygenase and cyclooxygenase can be reduced to monohydroxy fatty acids (HETEs) by peroxidase [43], which means the hydroxyl group is adjacent to a conjugated diene system. CYP2J5 can also facilitate the process, which has been confirmed in tubular cells, and metabolizes AA to 11-HETE and 15-HETE in mouse kidney [68]. The other is the formation of 19- and 20-Hydroxyeicosatetraenoic (19- and 20-HETE) by $\omega-1$ hydroxylation. The CYP $\omega$-hydroxylase that has been discovered so far is mainly in the CYP4 family. In kidney, proximal straight tubules are capable of converting AA to 20-HETE and 19(S)-HETE by $\omega$-hydroxylase [71]. What's more, 20-HETE is the main product of AA catalyzed by CYP $\omega$-hydroxylase, and in the human kidney, 20-HETE formation is mediated by both CYP4F2 and CYP4A11 [56,72]. Then, 20-HETE can be further oxidized to 20-carboxy arachidonic acid (20-COOH-AA) by alcohol dehydrogenase [73]. It is now well established from a few studies that, CYP4A1, CYP4A2, and CYP4A3 have remarkable AA $\omega$-hydroxylase activity [74]. Moreover, CYP4A1 as an arachidonate $\omega$-hydroxylase has a higher catalytic efficiency, with a turnover rate 20 times higher than that of CYP4A2 or CYP4A3 [74]. Besides, CYP4A1 can also convert AA to 11,12-EET in the mouse kidney [74].

\section{Mechanism of AA-induced Renal Inflammation}

\section{1. $P G s$ and Renal Inflammation}

PGs produced by the COX pathway, function differently in case of renal vascular disease. The impact of PGs on renal inflammation is mainly focused in the field of lupus nephritis (LN). In mice and humans, urinary prostaglandin D synthase (uPGDS) is considered as a biomarker of LN, which makes the role of $\mathrm{PGD}_{2}$ important in the development of $\mathrm{LN}$ [75]. $\mathrm{PGD}_{2}$ are considered as an inflammatory marker, while lipocalin-like-prostaglandin-D synthase (L-PGDS) is considered as a urinary biomarker for human active lupus nephritis [76]. One study of 184 longitudinal observations in 80 patients showed that lipocalin-like-prostaglandin-D synthase could predict the onset/remission of LN [77]. In patients with systemic lupus erythematosus (SLE), increased expression of $\mathrm{PGD}_{2}$ receptors (PTGDRs) in blood basophils causes an increase of $\mathrm{PGD}_{2}$ metabolites in the plasma [78]. $\mathrm{PGD}_{2}$ regulates the inflammatory response through two receptors, PTGDR-1 and PTGDR-2, which are also called D prostanoid receptor-1 (DP-1) and D prostanoid receptor-2 (DP-2). DP-2 also functions as the chemo-attractant receptor-homologous molecule, which is expressed on the Thelper type 2 (TH2) 
cells (CRTH2) $[79,80]$. Under in vivo condition, the targeted cells of $\mathrm{PGD}_{2}$ are mainly basophils, and the two PTGDRs are expressed at the highest level in the peripheral blood leukocytes. Interestingly, PTGDR-1 is ubiquitously expressed in the leukocytes, whereas PTGDR-2 only mediates the activation and chemotaxis of basophils, eosinophils, and CD4 ${ }^{+}$TH2 cells [81]. $\mathrm{PGD}_{2}$ and PTGDR induce the activation and infiltration of basophils in the kidneys of patients with SLE via mediating C-X-C motif ligand 12 (CXCL12) [78]. CXCL12 plays a biological role mainly through the chemokine receptor CXCR4, and regulates the physiological distribution of neutrophils in the kidney [82,83]. Inflammatory tissues and secondary lymphoid organs (SLOs) are associated with high levels of CXCL12, and CXCL12 mediates immune cell recruitment, which are the factors associated with the pathogenesis of SLE [78]. More importantly, basophil autocrine $\mathrm{PGD}_{2}$ is the main factor of PGD2-induced CXCR4 epoxidation. In humans and mice, the CXCL12-CXCR4 axis promotes the accumulation of basophils in SLOs during lupus through its mediating effect on the $\mathrm{PGD}_{2}$-PTGDR axis [78]. At the same time, we also can't deny the bad consequence caused by $\mathrm{PGE}_{2}$ and $\mathrm{TXB}_{2}$ in the LN. High levels of $\mathrm{PGE}_{2}$ and $\mathrm{TXB}_{2}$ promoted the activation of T cells and the production of IL-4 and IL-10 cytokines, which in turn leads to glomerulosclerosis in LN [84].

In addition, a potential link between PGs and tubulointerstitial lesions and glomerulonephritis was well studied. In the kidney with unilateral ureteral obstruction (UUO), $\mathrm{PGD}_{2}$ has penetrated all the sides of tubulointerstitial lesions by DP-2 expressed on CD4-positive T cells to activate Th2 lymphocytes. High levels of L-PGDS increased the degree of tubular fibrosis, while L-PGDS-knockout mice and prostaglandin D2 receptor CRTH2-knockout mice revealed a reduction in renal fibrosis, which may be related to the reduced infiltration of Th2 lymphocytes as well as reduced generation of the Th2 cytokines IL-4 and IL-13 [85]. In contrast, the PGD 2 metabolite, 15d-PGJ2, can activate $\operatorname{PPAR} \gamma$ and modulate the adhesion process via inhibiting the TNF $\alpha$-triggered IKK-NFKB pathway, which eventually suppresses inflammation in mouse renal tubular epithelial cells [86]. Moreover, PGs are also regulators of renal ischemia and vasoconstriction. Conversely, $\mathrm{PGl}_{2}$ and $\mathrm{PGE}_{1}$ have the effect of relaxing blood vessels and preventing hypoxia-mediated renal tissue damage. More importantly, in the case of renal artery stenosis, $\mathrm{PGl}_{2}$ and $\mathrm{PGE}_{1}$ selectively prevent tissue contraction and inhibit the decline of GFR $[87,88]$.

It is well known that $\mathrm{PGE}_{2}$ is the major product of the COX-2 pathway in the kidneys, which mediates kidney damage [89]. PGE2 play a crucial role in renal hemodynamics, renin release, and renal tubular sodium/water resorption [90,91]. In pathological environments such as diabetic nephropathy, PGE2 synthesis is increased, which may affect cell proliferation, differentiation or apoptosis [92,93]. Current studies indicate that four different EP receptors for $\mathrm{PGE}_{2}$ are closely associated with rapidly progressive glomerulonephritis (RPGN) [94]. In humans, EP1 receptor mRNA is predominantly expressed in the glomerulus [95]. In diabetic mouse models, activation of EP1 promotes the progression of diabetic nephropathy [96]. On the other hand, deletion of EP1 inhibited the down-regulation of nephrin, and improved glomerular basement membrane thickening and foot process regression [96]. In contrast, a few studies have shown that EP1 deficiency caused severe renal impairment in mice with glomerulonephritis, and the cause of this difference has not yet been discovered [97]. Interestingly, $\mathrm{PGE}_{2}$ has both vasodilation and vasoconstriction effects on renal afferent arterioles. Treatment with high concentrations of $\mathrm{PGE}_{2}$ (between 1 and $10 \mathrm{nmol} / \mathrm{L}$ ) caused arterial vasodilation, and at lower concentrations $(0.100 \mathrm{nmol} / \mathrm{L}), \mathrm{PGE}_{2}$ leads to vasoconstriction and aggravates hydronephrosis, which may be due to the binding of the EP3 receptor to the pertussis toxin (PTX)-sensitive G protein $G \alpha_{i}$. [98]. Glomerular hypertrophy caused by unilateral nephrectomy in mice may be associated with increased expression of EP2 [99]. In netrin-1-deficient mice, proximal tubular injury can be attributed to the COX-2-PGE 2 -mediated inflammatory response [100]. Further studies have confirmed that activation of the COX-2-PGE 2 -EP2 axis may be a specific response of podocytes to fluid flow shear stress. This appears to provide a mechanistic basis for changes in podocyte structure and glomerular filtration barrier, leading to proteinuria in high filtration-mediated renal injury [99]. EP3 also plays a paramount role in the progression of renal diseases. $\mathrm{Ep}^{-/-}-\mathrm{STZ}$ mice have less volume of urine and higher 
urine osmotic pressure compared with wild-type STZ (WT-STZ) mice, indicating enhanced water reabsorption. In parallel, the expressions of aquaporin-1, aquaporin-2, and urea transporter A1 in $\mathrm{Ep}^{-{ }^{--}}$-STZ mice were increased, so the presence of EP3 was an important promoting factor in the progression of renal disease [101]. EP4 is abundant in almost all types of kidney cells [95], and plays different roles at the glomeruli [102] and tubules [103]. The $\mathrm{G} \alpha_{\mathrm{s}}$-conjugated EP4 receptor directly activates adenylate cyclase, increases cAMP, and also activates phosphoinositide kinase $3[94,104]$. In addition, EP4 also stimulates AMP-activated protein kinase and COX2 in mouse podocytes in a p38-dependent manner [105]. When the rats were treated with a low-salt diet, EP4 transcripts in the glomeruli increased significantly, which in turn mediated $\mathrm{PGE}_{2}$-induced renin secretion and maintained renal blood flow [106]. More importantly, the overexpression of EP4 contributed to podocyte injury and compromised the glomerular filtration barrier in podocyte-specific EP4 receptor transgenic (EP4Pod+) mice after 5/6 nephrectomy [107]. On the other hand, in a rat model of cisplatin-induced renal failure, the COX1-PGE2-EP4 axis plays more important roles than dose COX-2 in regulating renal epithelial regeneration [108]. The endogenous $\mathrm{PGE}_{2}-\mathrm{EP} 4$ system is involved in tubule-interstitial fibrosis in a mouse UUO model. EP4 knockout significantly augmented obstruction-induced histological alterations. The effects of EP4 agonist are controversial. Use of EP4-sepicific agonist down-regulated the expression of renal macrophage chemokines and pro-fibrinogen growth factors, and inhibited the progression of renal inflammation [103]. In the rat model of acute renal failure, EP4 agonist reduces serum creatinine level and improve survival rate [109]. Moreover, in chronic kidney failure both EP2 and EP4 receptors are shown to be equally important in preserving the progression of chronic kidney disease [109]. In addition, PGE2 can alter renal cell growth, matrix transformation, fibrosis, and apoptosis by activating the EP4 receptor [89]. However, in a STZ-induced diabetic mouse model, the level of cytokines (TNF $\alpha$ and IL-6) and chemokines (MCP-1 and IP-10) in urine of EP4 agonist-treated mice were remarkably higher than those of vehicle-treated diabetes mice, which aggravated glomerular sclerosis and renal tubular interstitial fibrosis [110]. The exact mechanisms of EP4 agonists for the treatment of different kidney diseases need to be further studied.

\subsection{HETEs and Renal Inflammation}

It has been argued that the regulatory effects of HETEs on platelet function by autocrine or paracrine play a crucial role in the renal inflammation. In view of renal inflammation, which is often associated with renal vascular disease, HETEs have a dual role of anti-thrombotic and pro-thrombotic

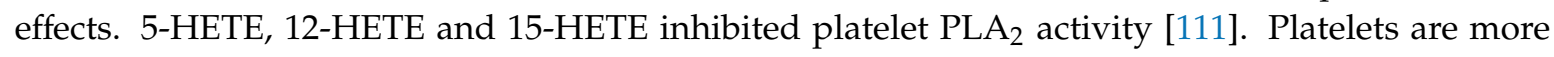
sensitive to ADP-induced aggregation, and mouse platelets disrupted by gene targeting 12-lipoxygenase $\left(\mathrm{P}-12 \mathrm{LO}^{-/-}\right)$of the 12-LOX gene exhibit selective hypersensitivity to ADP [112]. Current study found that in patients with type 2 diabetes, exogenous 12-HpETE activates platelet p38 mitogen-activated protein kinase (p38 MAPK), which in turn promotes the platelet activation in the oxidative stress-related pathophysiological states [113]. Under oxidative stress, a decrease in the glutathione peroxidase activity promotes the formation of 12-HpETE and further causes an increase in the phosphorylation level of p38 MAPK, which further activates platelets [113], exacerbating the kidney damage [114]. Therefore, HETE-induced renal inflammation can be achieved through the regulation of platelets.

In recent years, increasing literatures reveal the activation of peroxisome proliferator-activated receptors (PPARs) by HETEs. PPARs, with three isotypes (PPAR $\alpha$, PPAR $\delta$, and PPAR $\gamma$ ), are all transcriptional factors for lipogenesis and mainly expressed in the adipocytes and immune cells that regulate the expression of a quantity of genes associated with renal inflammation [115-117]. In macrophages, high concentrations of HETEs activate PPAR $\gamma[118,119]$, the latter gives rise to the increasing expression of CD36, which induces the apoptosis of tubule-interstitial cells, and ultimately leads to the inflammation and fibrosis of renal tubules [120]. In addition, HETEs can also activate PPAR $\alpha$ [121], which has an important effect on renal inflammation by participating in the regulation of lipid metabolism [122,123]. Moreover, the metabolite of 20-HETE, 20-COOH-AA, is an endogenous dual activator of PPAR $\alpha$ and PPAR $\gamma$, and its efficiency to activate PPAR $\gamma$ is twice than that of 20-HETE, 
revealing the potential modulatory effects of 20-COOH-AA on renal inflammation via activation of PPARs.

The roles of HETEs are also of interest in regulating the renal ion transport during renal inflammation. 20-HETE has a wide range of biological effects, including cell proliferation and angiogenesis, and is a relevant factor that regulates the renal function [124]. 20-HETE is widely synthesized in the renal tubules, including proximal tubules, thick ascending rings, small arteries of the renal cortex and the outer medulla. 20-HETE can fully bind to major vasoconstrictors, such as angiotensin II [125], adrenaline, and endothelin [126]. As early as 1991, Escalante had pointed out that both 20-HETE and 20-COOH-AA, acting similarly to furosemide, reduce the $\mathrm{Na}^{+}$and $\mathrm{K}^{+}$ concentrations of medullary thick ascending limb of Henle (mTALH) cells, suggesting the potential impact of HETEs on renal blood flow, GFR and urinary sodium excretion rates [127]. CYP4A11 is a key enzyme in the synthesis of 20-HETE. Both CYP4A and CYP4F belong to the CYP4 gene family, which catalyzes the conversion of arachidonic acid to 20-HETE [128]. The expression of CYP4A protein and the production of 20-HETE were significantly higher in the renal cortex and outer medulla of Dahl S salt-sensitive rats that fed either a low-salt or high-salt diet, indicating that the increased levels of renal 20-HETE in Dahl S rats promoted sodium retention and the development of salt sensitive hypertension [129]. Normalization of the 20-HETE levels with fibrates or transfer of wild-type CYP4A genes in congenic Dahl S strains is of great significance for inhibiting the progression of proteinuria and renal injury [129-131]. In the kidney, especially in the renal cortex, CYP4A also increases pressure natriuresis in the Dahl salt-sensitive rat [132]. The amount of 20-HETE metabolites in the CYP450 pathway produced by the extra renal medullary microsomes of salt-sensitive (SS/Jr) rats was significantly lower than that of salt-resistant (SR/Jr) rats [133].

In contrast, pharmacological inhibition of 20-HETE production in the outer medulla of the kidney in Lewis rats renders salt-sensitive [134], which means 20-HETE is a powerful vasoconstrictor in the kidney $[135,136]$. In renal microvessels, 20-HETE can strongly inhibit the activity of $\mathrm{Na}^{+} / \mathrm{K}^{+}$-ATPase and is a highly effective vasoconstrictor [137]. Increased production of 20-HETE in the renal microcirculation will decrease glomerular capillary pressure and GFR [124,138]. More importantly, 20-HETE can also reduce the pressure of post-glomerular circulation and ultimately promote the development of hypertension [138]. Interestingly though, 20-HETE-mediated increases in renal vascular resistance also reduce stress during glomerular circulation, thereby preventing the occurrence of glomerular damage caused by hypertension [139]. Therefore, when the synthesis of 20-HETE in the kidney is disturbed, the self-regulation of renal blood flow and the renal tubule-glomerular feedback system will be affected, resulting in reduced ion transport, increasing the difficulty of blood pressure control, and eventually aggravating glomerulonephritis and renal tubular interstitial nephritis [124]. The effect of 20-HETE on vascular function causes an ischemia-reperfusion injury (IRI) change that prolongs vasoconstriction after reperfusion and increased I/R injury [140]. It is well known that IRI is the most common cause of AKI, and 20-HETE production is elevated after renal ischemia (I/R) [141-143]. Use of 20-HETE analogues at a lower dosage can reduce the elevated plasma creatinine levels after I/R injury. In addition, 20-HETE analogues preconditioning reduced the area of tubular epithelial necrosis after I/R injury [143]. Moreover, 20-HETE can also be used to attenuate IRI by increasing medullary oxygen cooperation because it increases medullary blood flow and inhibits the renal tubular sodium transport $[143,144]$. On the other hand, in the kidney, 20-HETE overexpression significantly aggravated cell damage caused by I/R damage, which was mediated by the activation of caspase- 3 and partly by enhanced CYP4A-producing free radicals [140]. Thus, the relationship between 20-HETE and AKI may be further clarified. 20-HETE may also promote the progression of renal inflammation by mediating apoptosis $[145,146]$. Studies have proved that CYP4A and NADPH oxidase expression was up-regulated in glomeruli of diabetic OVE26 mice [145]. And hyperglycemia increases 20-HETE production and enhances 20-HETE-dependent ROS formation and apoptosis in the mouse podocytes and rat tubuli epithelial cells, while 20-HETE blockade reduces ROS and improves apoptosis and albuminuria $[145,146]$. Recent research indicated that 20-HETE can increase the TRPC6 activity in 
podocytes, secondary to podocytes and activate ROS production [147]. Activation of TRPC6 results in the disappearance of the foot processes, but eliminates the detachment of podocyte [148]. Similar to 20-HETE, the correlation between 19-HETE and renal inflammation is mainly achieved through its effects on renal hemodynamics and blood pressure, which will not be repeated here [149].

\subsection{LTs/LXs and Renal Inflammation}

As the major metabolite of the LOX pathway, LTs and LXs both play considerable roles in kidney inflammation. LTs are a class of powerful chemotactic molecules that regulate leukocyte migration and activation [150]. Current studies have confirmed increases of LTs and LXs in the kidneys after ischemia, which further mediates a series of inflammatory reactions leading to the kidney damage [151]. More importantly, studies have shown that renal tissue can produce LTs without relying on circulating inflammatory cells [152]. The action of $\mathrm{LTB}_{4}$ on neutrophil aggregation and infiltration and kidney tissue damage in the rat iARF model was first reported. In the rat kidney ischemia-reperfusion (I/R) model, $\mathrm{LTB}_{4}$ played a leading role in the polymorphonuclear neutrophils (PMNs) [153]. LTB 4 -dependent cells migrate to ischemic renal parenchyma and activate neutrophils, which can rapidly up-regulate leukocyte adhesion molecules, and then promote the initial infiltration of PMNs. Activated neutrophils induce endothelial cell injury, and vasodilation is blocked, further aggravating ischemic tubulointerstitial damage and causing a vicious circle of renal tissue damage [153]. A recent study by Landgraf on $\mathrm{LTB}_{4}$-mediated renal tissue inflammation has found that $\mathrm{LTB}_{4}$ and $\mathrm{LTD}_{4}$ inhibited the endocytosis of albumin in LLC-PK1 cells (pig kidney cells), attenuating the activation of protein kinase C (PKC) and protein kinase $\mathrm{B}$ (PKB) and thereby reducing the absorption of albumin. Meanwhile, in mice models, LTs inhibited the secretion of the anti-inflammatory cytokine IL-10, hindered the PI-3K/PKB pathway, and caused albumin overload that finally gave rise to tubule-interstitial damage $[154,155]$. After a few minutes of reperfusion, PMNs were recruited and $\mathrm{LTA}_{4}$ was immediately transformed into $\mathrm{LTB}_{4}$ in the kidney. Once PMNs entered the interstitial space, the above mechanism will be performed at high speed, thus accelerating the extensive migration of PMNs and forming a vicious cycle of tissue damage [153]. The role of LTs in glomerular injury has also been demonstrated in the nephrotoxic serum-induced glomerular injury model, due to increased recruitment/activation of polymorphonuclear cells and increased $\mathrm{LTB}_{4}$ production in the kidney, which eventually amplifies the reduction of glomerular filtration rate [156]. Moreover, $\mathrm{LTB}_{4}$ and $\mathrm{LTC}_{4} / \mathrm{D}_{4} / \mathrm{E}_{4}$ levels are both increased in patients with nephrotic syndrome (NS), and this may be the reason why the serum creatinine, diastolic blood pressure, and protein/creatinine ratio of patients are significantly reduced [157].

As another major metabolite of the LOX pathway, LXs are important endogenous anti-inflammatory lipid transmitters that have been discovered earlier and can act on a variety of cells, including neutrophils, mononuclear macrophages, mesangial cells etc., to exert complex anti-inflammatory effects [158-160]. In glomerulonephritis, LXA 4 inhibits LTs and reduces further infiltration of leukocytes $[161,162]$. In acute poststreptococcal glomerulonephritis (APSGN), one of the crucial pathological effects is the infiltration of neutrophils and monocytes in the glomeruli during the acute phase [163]. In vitro experiments with human mesangial cells showed that very low concentrations of $\mathrm{LXA}_{4}(1-10 \mathrm{nmol} / \mathrm{L})$ inhibited the expression of cell fibrosis-related genes induced by platelet-derived growth factor and connective tissue growth factor [164]. Leukocytes infiltrate and $\mathrm{LTB}_{4}$ synthesis increases in rat kidneys at the early stage after nephrotoxic serum injection. At the same time, IL-4 and IL-13 produced by Th2 cells stimulate glomerular expression of LOX and synthesis of 15S-HETE and $\mathrm{LXA}_{4}$. The later inhibits $\mathrm{LTB}_{4}$ signaling, reduces leukocyte chemotaxis and transforms neutrophil infiltration into mononuclear macrophage infiltration, resulting in removal of apoptotic neutrophils and repairmen of tissue damage $[165,166]$. Another nephritis involving LXs is Henoch-Schonlein purpura nephritis (HSPN), which is a common secondary glomerulonephritis in pediatrics [167]. In HSPN, both plasma and urinary levels of $\mathrm{LTB}_{4}$ and $\mathrm{LTE}_{4}$ increase, while $\mathrm{LXA}_{4}$ levels decrease, indicating that endogenous $\mathrm{LXA}_{4}$ deficiency may be one of the causes of HSPN (which provides a basis for exploring new methods for the treatment of HSPN) [167]. Recent studies have shown that LXs 
inhibited the increase of renal/body weight ratio in diabetic animals and also reduced the glomerular dilatation and mesangial matrix deposition, in both high-fat diet-induced diabetes mouse model and unilateral ureteral obstruction (UUO) mouse model $[168,169]$. In addition, LXs can significantly reduce proteinuria and play an important role in reversing the CKD induced in diabetic $A p o E^{-/-}$male mice [170]. In cultured human renal epithelial cells, treatment with LXs reduced TNF- $\alpha$-driven Egr-1 activation, which may regulate the inflammation of kidney disease [170] [171,172]. As Egr-1 activity is elevated in renal tubular cells in patients with renal failure [173], this may be related to Egr-1, which mediates the TGF- $\beta$ signaling pathway in the kidney, immune cell infiltration, and regulates the NF- $\mathrm{kB}$ activity and cytokine/chemokine expression in the kidney [173]. Brennan et al. had identified that Egr-1 as a downstream target for LXs, besides, they also confirmed the interaction between LXs and Egr-1 in studies of human renal tubular epithelial cells [170]. In summary, LXs have a significant positive effect on inhibiting kidney inflammation.

\subsection{EETs and Renal Inflammation}

It has been reported that 14,15-EET can alleviate the proteinuria and renal dysfunction caused by cyclosporine, which may be related to the inhibition of inflammatory cells infiltration into the kidney and reduction of renal fibrosis [174]. In the rat model of renal tubule-interstitial inflammation induced by unilateral ureteral obstruction (UUO), sEH deficiency has a beneficial effect on renal fibrosis and interstitial inflammation. The molecular mechanism may be associated with lack of sEH and the reduction of EETs degradation, which inhibited the transforming growth factor (TGF)-1/Smad3 signaling, diminished infiltration of neutrophils and macrophages, prevented expression levels of NF- $\mathrm{KB}$ target gene proteins (TNF- $\alpha$ and ICAM-1), decrease cell death caused by ROS, and causes PPAR inactivation [175]. Manhiani proved that soluble epoxide hydrolase gene deletion attenuated renal injury and inflammation with DOCA-salt hypertension [176]. In the kidney, EET has anti-inflammatory effects by blocking the activation of NF-kB and inhibiting the progression of renal inflammation by reducing renal macrophage infiltration [176]. Research also showed that, increased production of EET prevented microalbuminuria and kidney inflammation in the hyperglycemic overweight mice [177]. However, in the kidney, EET/DHET-ratios were increased in sEH knockout mice, but surprisingly, plasma creatinine concentration and IRI were higher than in the control group, which may be due to the formation of 20-HETE that eliminates the potentially beneficial effects of EET degradation [178]. In an I/R-induced AKI mouse model, the administration of 14,15-EET alleviated the dilated renal tubules, leading to an obvious reduction in plasma Cr, TNF- $\alpha$ and IL-6 [179]. These effects, discovered in I/R-caused AKI mice, may be due to the 14,15-EET reversing the I/R-induced declination of $\mathrm{p}-\mathrm{GSK} 3 \beta$ expression, which induced the ratio of $p$-GSK3 $\beta / G S K 3 \beta$ back to a normal level [180]. In addition, the CYP450-derived eicosanoids could activate the eNOS and NO release. 14,15-EET can activate the endothelial cell NO synthase (eNOS) and NO release by blocking the $\mathrm{Ca}^{2+}$-activated $\mathrm{K}^{+}$, which eventually caused afferent arteries dilatation and reduces renal inflammation [181]. 5,6-EET, found in the kidneys of rabbits, is involved in the metabolism of two types of vasodilators, one being $\mathrm{PGE}_{2} / \mathrm{PGI}_{2}$ and the other being the adenosine analogue 5,6-epoxy-PGE [182]. In contrast, in the rat I/R kidney model, 5,6-EET caused COX-dependent renal vasoconstriction, whereas in isolated rat kidneys, 5,6-EET dilated blood vessels. In spontaneously hypertensive rats, 5,6-EET and 11,12-EET induced renal vasodilation more than 2 times greater than in Wistar Kyoto rats [183]. Stimulation of EETs activating adenosine 2A (A2A) may be an important mechanism for regulating microvascular tension in glomeruli [184]. It has been reported that 11,12-EET may represent an A2A-mediated mediator of glomerular microvascular expansion in rats. In rat glomerular pre-microvasculature, EET release was an important step in the activation of A2A receptors and adenylyl cyclase activation, and EETs mediated the activation of the Gs alpha protein by stimulating mono-ADP-ribosyltransferase [185]. The mechanism by which 11,12-EET dilates the afferent arterioles is possibly due to the phosphorylation of protein phosphatase $2 \mathrm{~A}$ activity and $\mathrm{Ca}^{2+}$-activated $\mathrm{K}^{+}$channels [186]. Recent research has proven that 11,12-EET is a major product of Cyp2c44 in mice, which is involved in regulating the excretion of epithelial sodium in 
the collecting duct. Cyp2c44 in the collecting duct can promote the excretion of $\mathrm{Na}^{+}$in the kidney under high salt or high $\mathrm{K}^{+}$environment by inhibiting epithelial $\mathrm{Na}^{+}$channel $(\mathrm{ENaC})$, thus preventing excessive $\mathrm{Na}^{+}$absorption, suggesting that 11,12 -EET may indirectly affect the renal inflammation through its role in regulation of blood pressure [187]. It is worth mentioning that 8,9-EET has a unique protective effect on the glomerulus [188]. Exogenous 8,9-EET (1-1000 nM) dose-dependently prevented a circulating permeability factor (FSPF)-induced increase in the glomerular albumin permeability [188]. The other three EET regioisomers, 8,9-EET metabolite, 8,9-dihydroxyeicosatrienoic acid and unrelated 11,14-eicosadienoic acid were ineffective, indicating the specificity of 8,9-EET for glomerular protection [188]. More importantly, a synthetic analog of 8,9-EET containing a double bond antagonized the effect of 8,9-EET on FSPF-induced increase in glomerular albumin permeability. These results indicate that the development of stable analogs of 8,9-EET may make sense to the effective management of glomerular dysfunction [188].

\section{Treatments}

A number of drugs for kidney inflammation based on the AA metabolic pathway are in the early stages of development for human disease treatment, and their study output is limited. The treatment of kidney disease based on AA is varied and many factors are involved, so here we only introduce strategies that are relevant to humans (Table 1).

Table 1. Drugs related to AA metabolism for kidney inflammation.

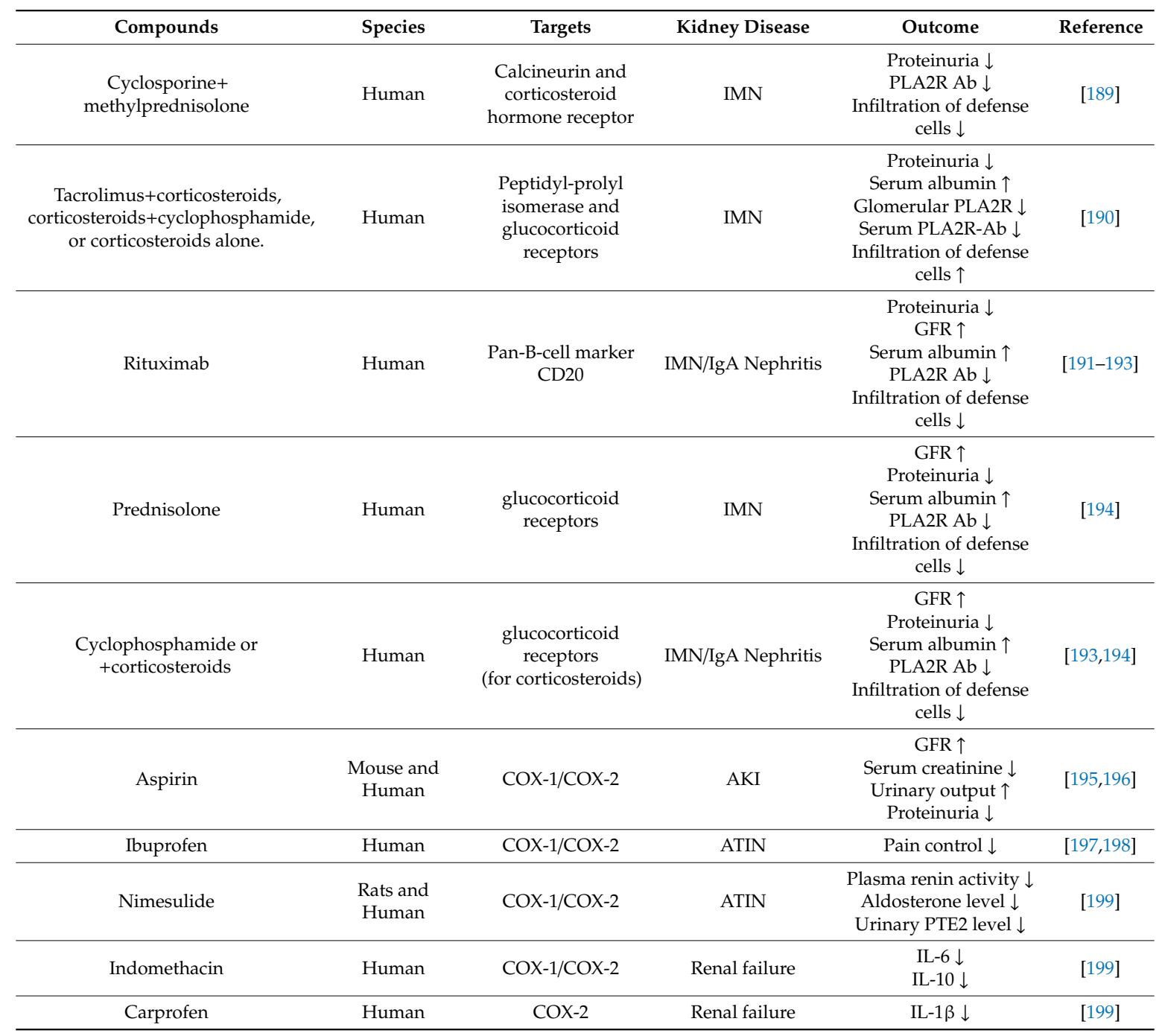


Table 1. Cont.

\begin{tabular}{|c|c|c|c|c|c|}
\hline Compounds & Species & Targets & Kidney Disease & Outcome & Reference \\
\hline Diclofenac acid & $\begin{array}{l}\text { Rats and } \\
\text { Human }\end{array}$ & $\mathrm{COX} 1 / \mathrm{COX} 2$ & Renal cancer & PGE2 level $\downarrow$ & [200] \\
\hline Zileuton & $\begin{array}{c}\text { Human } \\
\text { Mesangial Cells }\end{array}$ & LOX/COX-2 & Renal cancer & $\begin{array}{c}\text { Serum creatinine } \downarrow \\
\text { Interstitial fibrosis } \downarrow\end{array}$ & [201] \\
\hline Licofelone & $\begin{array}{l}\text { Mouse and } \\
\text { Human }\end{array}$ & 5-LOX/COX & Glomerulonephritis & $\begin{array}{l}\text { IL-18 } \downarrow \\
\text { PGE2 } \downarrow\end{array}$ & [201] \\
\hline Baicalein & Mouse & 12/15-LOX & $\begin{array}{c}\text { Diabetic } \\
\text { nephropathy }\end{array}$ & $\begin{array}{c}\text { 12-HETE } \downarrow \\
\text { IL-6 } \downarrow \\
\text { Proteinuria } \downarrow\end{array}$ & [202] \\
\hline PVPA & Rats & CYP450 & $\begin{array}{l}\text { Acute and chronic } \\
\text { glomerulonephritis }\end{array}$ & $\begin{array}{c}\text { Proteinuria } \downarrow \\
\text { Apoptosis in tubular } \\
\text { epithelial cells } \downarrow \\
\text { Generation of reactive } \\
\text { oxygen species } \downarrow\end{array}$ & [174] \\
\hline
\end{tabular}

\subsection{Phospholipase-Associated Therapy}

Current research has suggested that the M-type phospholipase $\mathrm{A} 2$ receptor $\left(\mathrm{PLA}_{2} \mathrm{R}\right)$ is sensitive and specific for idiopathic membranous nephropathy (MN). Serum phospholipase $A_{2}$ receptor antibody $\left(\mathrm{PLA}_{2} \mathrm{R} \mathrm{Ab}\right.$ ) and circulating anti-phospholipase $\mathrm{A}_{2}$ receptor antibodies (anti-PLA2R Abs) are now regarded as a valuable indicator of prognosis for patients with nephritis, especially in patients with idiopathic membranous nephropathy (IMN) [203,204]. IMN is one of the most common causes of adult primary NS. The KDIGO guidelines have recommend treatment with glucocorticoids and immunosuppressive agents for IMN $[191,194]$. Beck et al. reported that 35 patients with IMN were treated with rituximab (the anti- autoimmune disease drug), within whom $71 \%$ of patients were serum anti-PLA $A_{2} \mathrm{R}$-positive. After 12 months of rituximab therapy, serum anti-PLA ${ }_{2} \mathrm{R}$ decreased or disappeared in 17 (68\%) of these patients. After 12 months and 24 months of therapy, the rates of complete remission (CR) and partial response (PR) were $59 \%$ and $88 \%$, respectively, and the decrease in antibody titer was earlier than the remission of proteinuria [189]. An earlier study of 37 biopsy confirmed IMN patients indicated that, after receiving standard immunosuppressive therapy (cyclosporine combined with methylprednisolone), the titer of $\mathrm{PLA}_{2} \mathrm{R}-\mathrm{Ab}$ positive patients gradually decreased with an ameliorated proteinuria [190]. A retrospective study that includes 113 IMN patients showed that, the tacrolimus (TAC) and corticosteroids, corticosteroids and cyclophosphamide (CYC) and corticosteroids alone respectively can decrease the serum $\mathrm{PLA}_{2} \mathrm{R}-\mathrm{Ab}$ titer and proteinuria in IMN patients [192]. As a conventional anti-tumor drug, rituximab seems to have a favorable result on MN [205]. 8 months after receiving rituximab, 22 patients with PLA $_{2}$ R-related MN showed a decrease of proteinuria and $\mathrm{PLA}_{2} \mathrm{R} \mathrm{Ab}$ titer. At the meantime, renal function remained stable, and serum albumin increased [205]. Similar results were obtained in Beck's study, which suggested that rituximab can inhibit the progression of IMN by lowering the $P_{2} A_{2} R A b$ titer [189]. Lowered PLA $A_{2} R$ $\mathrm{Ab}$ titer could also be achieved by oral administration of prednisolone or cyclical cyclophosphamide (CTX) or cyclophosphamide or mycophenolate mofetil (MMF) in combination with steroids in IMN patients, showing a beneficial result with elevated glomerular filtration rate (eGFR) [191,193]. A recent study showed that combination with corticosteroids and rituximab also decreases the serum creatinine and $\mathrm{PLA}_{2} \mathrm{R}-\mathrm{Ab}$ level [206]. However, one cannot ignore the fact that steroid treatment aggravated tubule-interstitial fibrosis in patients with acute interstitial nephritis [207]. A recent study also reported that corticosteroid treatment seems to increase the recurrence rate of TIN [208], suggesting that the $\mathrm{PLA}_{2} \mathrm{R}-\mathrm{Ab}$ therapy may only work in IMN patients. The data from this research seems contradictory, especially the small sample size, which makes it difficult to draw firm conclusions regarding their outcomes. Therefore, the prospect of corticosteroids for the anti- PLA 2 R-Ab therapy needs more research and exploration. 


\subsection{COX-Associated Therapy}

Nonsteroidal anti-inflammatory drugs (NSAIDs) are the main COX inhibitors. Their common mechanism of action is the inhibition of COX, and the most important result of this inhibition is the reduction of the production of PGs, thus playing anti-inflammatory, pain relieving and antipyretic roles [209]. COX inhibitors fall into two broad categories: non-specific COX inhibitors and specific COX-2 inhibitors. Among them, aspirin, ibuprofen, naproxen, etc. are usually used as non-specific COX inhibitors in the treatment of nephritis. Certain functional groups of COX-2 inhibitors (coxibs) can insert into the hydrophobic cavity formed by some amino acid residues of COX-2, causing the loss of their catalytic function [18]. In this case, AA cannot perform biological transformations under the catalysis of COX-2, thus blocking the synthesis of PGs as well as the inflammatory process [58]. Aspirin, also known as acetylsalicylic acid, is a well-known antipyretic analgesic that inhibits platelet aggregation and prevents thrombosis, which could also be used in kidney inflammatory diseases [210]. Aspirin is a non-specific COX inhibitor that inhibits both COX-1 and COX-2, which has a good effect on the prevention of primary and secondary thrombosis [211-213]. Aspirin treatment in $\mathrm{MRL} / \mathrm{MpJ}-\mathrm{Fas}^{l p r} / \mathrm{J}$ (MRL/lpr) mouse could alleviate LN [195] and reduce the risk of platelet aggregation and micro-embolization, which may improve the GFR during renal perfusion, thereby improving kidney function [196]. At the same time, perioperative aspirin can reduce the thromboxane level in the urine, which is a powerful vasoconstrictor, and improve renal function [196]. A large prospective cohort study of more than 5000 patients undergoing cardiac surgery indicated that patients taking aspirin had a lower incidence of AKI than patients who did not take aspirin $(P<0.001)$ [214]. Above all, the incidence of renal failure was reduced by $74 \%$ in those who were taking aspirin [214]. However, according to a recent study, low-dose aspirin oral intake was shown to have no significant effect on kidney function during the 15 years after kidney transplantation [215]. This may be because aspirin can be rapidly hydrolyzed to salicylate immediately, a product that has an almost negligible effect on COX [210]. Further, the results found that aspirin increased the risk of massive hemorrhage and further increased the risk of subsequent AKI [197]. Since the findings in numerous studies are contradictory, additional research on the value of aspirin for kidney inflammation is essential.

As the most widely used NSAID, ibuprofen is the first choice for the treatment of inflammatory pain [198]. Compared with other NSAIDs and coxibs, ibuprofen has fewer side effects on the gastrointestinal tract and a relatively low incidence of liver and kidney damage [216]. However, the amount of urine was obviously reduced after the first day of treatment with ibuprofen in premature infants, and the serum creatinine concentration was significantly increased on the third day of treatment [217]. There seems to be a latent relationship between ibuprofen and acute tubule-interstitial nephritis (ATIN), which is a major factor contributing to the acute renal insufficiency that must be kept in mind when it is used for treatment $[199,218,219]$.

Nimesulide, another NSAID, has selective inhibition of COX-2 and qualitative inhibition of COX-1, and the principal effect of nimesulide on kidney inflammation mainly involves renal hemodynamics and electrolyte excretion. The use of nimesulide in healthy volunteers during long-term use of furosemide causes a brief and acute decline in renal hemodynamics and attenuated the natriuretic, kaliuretic and diuretic effects of furosemide [220]. Nimesulide reduced the plasma renin activity, aldosterone levels, and urinary $\mathrm{PTE}_{2}$ levels [220]. Meanwhile, diuretic-induced renin activity was attenuated by nimesulide. This suggests that nimesulide protects kidney function by allowing sodium and potassium retention [220]. However, it is interesting to remark that there was no significant change in serum creatinine and Tamm-Horsfall glycoprotein (THG) concentrations as well as no significant effect on GFR after nimesulide in 16 healthy human volunteers [221]. The weak effect of nimesulide on renal toxicity may suggest that it has no strong inhibitory effect on renal COX at the therapeutic dose, which is similar to the results from Ceserani et al., who showed that nimesulide did not dramatically reduced urinary $\mathrm{PTE}_{2}$ excretion in rats [222]. 
Several other NSAIDs also plays active role in the treatment of nephritis. Carprofen, an inhibitor of COX-mediated PG synthesis, increased the thick ascending limb of the loop of Henle at the tubular level and increased resorption of solute in the medullary segment of the upper extremity, thereby reducing sodium and chlorine excretion and potentially improving GFR or overall excretion of solute in the human kidney [200]. Diclofenac acid can reduce the recurrence survival rate and improve the survival rate of patients with renal cancer after surgery, which may be related to the fact that diclofenac acid inhibits the production of $\mathrm{PGE}_{2}$, which in turn inhibited the process by which $\mathrm{PGE}_{2}$ alters intracellular cyclic adenosine monophosphate levels to reduce the number and activity of natural killer cells [223-225].

However, as a COX-2 inhibitor, rofecoxib increases the risk of major cardiovascular events during treatment [226]. In addition, naproxen and celecoxib were related to the occurrence of AKI [227]. Studies have associated people who take naproxen, regardless of the dosage, with a higher risk of nephrotic syndrome and AIN [228]. Other NSAIDs may also have potential adverse effects on renal function [229], such as indomethacin, which can cause acute sodium retention in healthy adults and reduce GFR levels by inhibiting COX [230]. Studies have shown that live-donor nephrectomy patients that were treated with ketolic acid had significant increases of urinary albumin/creatinine ratio after 1 year and is an independent risk factor for reducing GFR (odds ratio 1.38) [231]. A study from Lancet indicated that NSAIDs, such as rofecoxib, celecoxib, ibuprofen, naproxen, and diclofenac, increase the risk of vascular events during treatment [232]. However, it has also been pointed out that all COX-2 inhibitors did not significantly promote renal events and arrhythmia events [233]. These findings provide insight for future research, and prospective clinical trials are needed to assess the curative effect and safety of NSAIDs for the treatment of renal inflammation.

\subsection{LOX-Associated Therapy}

The research related to LOX-associated therapy is mostly studied on experimental animals, and when it comes to human studies, zileuton is often mentioned. Zileuton blocks the conversion of AA to $\mathrm{LTB}_{4}$ by inhibiting the 5-LOX activity and is often used for the prevention of inflammation-related diseases and for cancer treatment [234]. However, whether zileuton could be used to treat renal inflammation in humans still needs to be further confirmed by clinical trials. Licofelone is a novel dual anti-inflammatory drug that inhibits both COX and 5-LOX. A study has indicated that licofelone improved inflammation in human mesangial cells (HMCs) exposed to IL-18 in a dose-dependent manner, through inhibiting COX-2 enzyme activity and reducing PGE 2 release in HMCs [201]. Similarly, licofelone inhibited IL-18-induced 5-LOX enzyme activity and thereby reduces leukotriene release. In addition, licofelone blocked IL-18-induced phosphorylation of $\mathrm{p} 38$ proliferation protein kinase, inhibited the expression of monocyte chemoattractant protein 1 and interferon- $\gamma$. Licofelone also suppressed mesangial cell proliferation caused by IL-18 [201]. These results indicate that licofelone alleviates human glomerular inflammation by inhibiting IL-18-induced proinflammatory cytokine release and cell proliferation. A more exciting result was that licofelone inhibited IL-18-induced mesangial cell proliferation, and the results indicated that licofelone might be effective for the treatment of glomerulonephritis in children [201]. 2,3-diarylxanthones, dual inhibitors of COX and 5-LOX, are capable of preventing the production of $\mathrm{LTB}_{4}$ in human neutrophils as well as decreasing $\mathrm{PGE}_{2}$ production in human whole blood in a concentration-dependent manner [235]. According to the current results, the effect of lox-related drugs in regulating inflammation is still in the experimental study stage. Baicalein, a 12/15-LOX inhibitor, was demonstrated to prevent the elevation in renal 12-HETE production and reduce renal inflammation in strptozotocin-induced diabetic mice [202].

\subsection{CYP450/sEH-Associated Therapy}

There are two pharmacological approaches that have been used to chronically elevate endogenous levels of EETs in order to evaluate their renal and vascular protective effects in vivo. One approach is to increase the levels of EETs by inducing epoxygenases with fibric acid derivatives such as 
clofibrate, fenofibrate, and bezafibrate [236]. Fenofibrate has been shown to strongly induce renal protein expression of CYP2C23, a major CYP epoxygenase in the rat kidney, and increase the renal epoxygenase activity [236]. We have previously reported that a CYP450 inducer, gemfibrozil, has shown positive effects on CYP2C-related non-alcoholic steatotic hepatitis [237]. More importantly, the potential link between dyslipidemia and renal inflammation also reveals the potential values of fibric acid derivatives for the treatment of renal inflammation $[238,239]$ among diabetic dyslipidemia patients [240-242]. However, some reports suggested that, the combined action of metamizole and gemfibrozil could synergistically affect the proximal tubule and increase the chances of renal damage [243]. Some studies have shown that the epoxyeicosatrienoic acid analog can effectively slow down the kidney damage associated with oxidative stress, inflammation, and endoplasmic reticulum stress $[244,245]$. For example, a new oral drug, PVPA, reduces the proteinuria and renal dysfunction caused by cyclosporine, inhibits the inflammatory cell infiltration in the kidney, and reduces the renal fibrosis [174]. Warfarin, an anticoagulant, is mainly metabolized by CYP2C [246-248], which can inhibit the proliferation of mesangial cells by interfering with the activation of Gas6, and plays an important role in the treatment of various human kidney diseases, such as acute and chronic glomerulonephritis and diabetic nephropathy [249].

Another approach to elevate EETs is to inhibit the conversion of EETs to their less active metabolites by soluble epoxide hydrolase (sEH) [250]. sEH plays a major role in several diseases, including hypertension, cardiac hypertrophy, arteriosclerosis [251]. Because of its possible role in cardiovascular and other diseases, $\mathrm{sEH}$ is being pursued as a pharmacological target, and potent small molecule inhibitors are available [252]. Such inhibitors, like UC1153 (AR9281) and GSK2256294, were taken to clinical trials for treatment of hypertension and chronic obstructive pulmonary disease respectively [252]. However, even with the promise of epoxygenase metabolites to protect the kidney and vasculature, further research in this area is necessary in view of the small number of trials on humans.

\section{Conclusions}

The present review aims to discuss the effect of AA metabolism on kidney inflammation, as well as to provide a theoretical basis for the treatment of kidney inflammation. AA metabolism and kidney inflammation are closely linked in multiple ways. Through a summary of previous studies, our conclusions help us to understand the effects of AA metabolism on the kidney in several ways and provide the therapeutical treatment for renal inflammation. However, the studies on the treatment of kidney inflammation based on AA metabolism require a large sample of randomized controlled trails to elucidate their efficacy.

Author Contributions: Z.W., and Z.G. conceived and designed the article; T.W., X.F., Z.G., Z.W., Q.C. and D.W. wrote the paper. J.K.P and D.W. edited the manuscript. All authors read and approved the manuscript.

Funding: This work was funded by the National Key Research and Development Program of China, grant number [2017YFC1702703], the Key R\&D programs in Shandong, grant number [2016CYJS08A01-1], and the National Science Foundation of China, grant number [81473369].

Conflicts of Interest: The authors declare no conflict of interest.

\section{References}

1. Van Dorp, D.A. Essential fatty acid metabolism. Proc. Nutr. Soc. 1975, 34, 279-286. [CrossRef] [PubMed]

2. Sperling, R.I.; Benincaso, A.I.; Knoell, C.T.; Larkin, J.K.; Austen, K.F.; Robinson, D.R. Dietary omega-3 polyunsaturated fatty acids inhibit phosphoinositide formation and chemotaxis in neutrophils. J. Clin. Investig. 1993, 91, 651-660. [CrossRef] [PubMed]

3. De Jonge, H.W.; Dekkers, D.H.; Lamers, J.M. Polyunsaturated fatty acids and signalling via phospholipase C-beta and A2 in myocardium. Mol. Cell. Biochem. 1996, 157, 199-210. [CrossRef] [PubMed]

4. Calder, P.C. Marine omega-3 fatty acids and inflammatory processes: Effects, mechanisms and clinical relevance. Biochim. Biophys. Acta 2015, 1851, 469-484. [CrossRef] [PubMed] 
5. Yates, C.M.; Calder, P.C.; Ed Rainger, G. Pharmacology and therapeutics of omega-3 polyunsaturated fatty acids in chronic inflammatory disease. Pharmacol. Ther. 2014, 141, 272-282. [CrossRef] [PubMed]

6. Rae, S.A.; Davidson, E.M.; Smith, M.J. Leukotriene B4, an inflammatory mediator in gout. Lancet 1982, 2, 1122-1124. [CrossRef]

7. Arachidonic acid, analgesics, and asthma. Lancet 1981, 2, 1266-1267.

8. Rand, A.A.; Barnych, B.; Morisseau, C.; Cajka, T.; Lee, K.S.S.; Panigrahy, D.; Hammock, B.D. Cyclooxygenase-derived proangiogenic metabolites of epoxyeicosatrienoic acids. Proc. Natl. Acad. Sci. USA 2017, 114, 4370-4375. [CrossRef]

9. Kopp, B.T.; Thompson, R.; Kim, J.; Konstan, R.; Diaz, A.; Smith, B.; Shrestha, C.; Rogers, L.K.; Hayes, D., Jr.; Tumin, D.; et al. Secondhand smoke alters arachidonic acid metabolism and inflammation in infants and children with cystic fibrosis. Thorax 2019, 74, 237-246. [CrossRef]

10. Chauhan, G.; Roy, K.; Kumar, G.; Kumari, P.; Alam, S.; Kishore, K.; Panjwani, U.; Ray, K. Distinct influence of COX-1 and COX-2 on neuroinflammatory response and associated cognitive deficits during high altitude hypoxia. Neuropharmacology 2019, 146, 138-148. [CrossRef]

11. Goldstein, A.R.; White, R.H.; Akuse, R.; Chantler, C. Long-term follow-up of childhood Henoch-Schonlein nephritis. Lancet 1992, 339, 280-282. [CrossRef]

12. Murakami, M.; Nakatani, Y.; Kuwata, H.; Kudo, I. Cellular components that functionally interact with signaling phospholipase A(2)s. Biochim. Biophys. Acta 2000, 1488, 159-166. [CrossRef]

13. Dubois, R.N.; Abramson, S.B.; Crofford, L.; Gupta, R.A.; Simon, L.S.; Van De Putte, L.B.; Lipsky, P.E. Cyclooxygenase in biology and disease. FASEB J. 1998, 12, 1063-1073. [CrossRef] [PubMed]

14. Lambert, I.H.; Hoffmann, E.K.; Christensen, P. Role of prostaglandins and leukotrienes in volume regulation by Ehrlich ascites tumor cells. J. Membr. Biol. 1987, 98, 247-256. [CrossRef] [PubMed]

15. Lipsky, P.E.; Brooks, P.; Crofford, L.J.; DuBois, R.; Graham, D.; Simon, L.S.; van de Putte, L.B.; Abramson, S.B. Unresolved issues in the role of cyclooxygenase-2 in normal physiologic processes and disease. Arch. Intern. Med. 2000, 160, 913-920. [CrossRef] [PubMed]

16. Ricciotti, E.; Yu, Y.; Grosser, T.; Fitzgerald, G.A. COX-2, the dominant source of prostacyclin. Proc. Natl. Acad. Sci. USA 2013, 110, E183. [CrossRef] [PubMed]

17. Thuresson, E.D.; Lakkides, K.M.; Rieke, C.J.; Sun, Y.; Wingerd, B.A.; Micielli, R.; Mulichak, A.M.; Malkowski, M.G.; Garavito, R.M.; Smith, W.L. Prostaglandin endoperoxide H synthase-1: The functions of cyclooxygenase active site residues in the binding, positioning, and oxygenation of arachidonic acid. J. Biol. Chem. 2001, 276, 10347-10357. [CrossRef]

18. Hawkey, C.J. COX-2 inhibitors. Lancet 1999, 353, 307-314. [CrossRef]

19. Kawahara, K.; Hohjoh, H.; Inazumi, T.; Tsuchiya, S.; Sugimoto, Y. Prostaglandin E2-induced inflammation: Relevance of prostaglandin E receptors. Biochim. Biophys. Acta 2015, 1851, 414-421. [CrossRef]

20. Smith, W.L.; Garavito, R.M.; DeWitt, D.L. Prostaglandin endoperoxide H synthases (cyclooxygenases)-1 and -2. J. Biol. Chem. 1996, 271, 33157-33160. [CrossRef]

21. Naraba, H.; Murakami, M.; Matsumoto, H.; Shimbara, S.; Ueno, A.; Kudo, I.; Oh-ishi, S. Segregated coupling of phospholipases A2, cyclooxygenases, and terminal prostanoid synthases in different phases of prostanoid biosynthesis in rat peritoneal macrophages. J. Immunol. 1998, 160, 2974-2982. [PubMed]

22. Smith, W.L.; Song, I. The enzymology of prostaglandin endoperoxide H synthases-1 and -2. Prostaglandins Other Lipid Mediat. 2002, 68-69, 115-128. [CrossRef]

23. Bahia, M.S.; Katare, Y.K.; Silakari, O.; Vyas, B.; Silakari, P. Inhibitors of microsomal prostaglandin E2 synthase-1 enzyme as emerging anti-inflammatory candidates. Med. Res. Rev. 2014, 34, 825-855. [CrossRef] [PubMed]

24. Hecker, M.; Haurand, M.; Ullrich, V.; Diczfalusy, U.; Hammarstrom, S. Products, kinetics, and substrate specificity of homogeneous thromboxane synthase from human platelets: Development of a novel enzyme assay. Arch. Biochem. Biophys. 1987, 254, 124-135. [CrossRef]

25. Goetzl, E.J.; An, S.; Smith, W.L. Specificity of expression and effects of eicosanoid mediators in normal physiology and human diseases. FASEB J. 1995, 9, 1051-1058. [CrossRef] [PubMed]

26. Stenson, W.F. The universe of arachidonic acid metabolites in inflammatory bowel disease: Can we tell the good from the bad? Curr. Opin. Gastroenterol. 2014, 30, 347-351. [CrossRef] [PubMed]

27. Alhouayek, M.; Muccioli, G.G. COX-2-derived endocannabinoid metabolites as novel inflammatory mediators. Trends Pharmacol. Sci. 2014, 35, 284-292. [CrossRef] 
28. Li, H.S.; Hebda, P.A.; Kelly, L.A.; Ehrlich, G.D.; Whitcomb, D.C.; Dohar, J.E. Up-regulation of prostaglandin EP4 receptor messenger RNA in fetal rabbit skin wound. Arch. Otolaryngol. Head Neck Surg. 2000, 126, 1337-1343. [CrossRef]

29. Breyer, R.M.; Bagdassarian, C.K.; Myers, S.A.; Breyer, M.D. Prostanoid receptors: Subtypes and signaling. Annu. Rev. Pharmacol. Toxicol. 2001, 41, 661-690. [CrossRef]

30. Sandulache, V.C.; Chafin, J.B.; Li-Korotky, H.S.; Otteson, T.D.; Dohar, J.E.; Hebda, P.A. Elucidating the role of interleukin 1beta and prostaglandin E2 in upper airway mucosal wound healing. Arch. Otolaryngol. Head Neck Surg. 2007, 133, 365-374. [CrossRef]

31. Bauer, J.; Ripperger, A.; Frantz, S.; Ergun, S.; Schwedhelm, E.; Benndorf, R.A. Pathophysiology of isoprostanes in the cardiovascular system: Implications of isoprostane-mediated thromboxane A2 receptor activation. Br. J. Pharmacol. 2014, 171, 3115-3131. [CrossRef] [PubMed]

32. Ekambaram, P.; Lambiv, W.; Cazzolli, R.; Ashton, A.W.; Honn, K.V. The thromboxane synthase and receptor signaling pathway in cancer: An emerging paradigm in cancer progression and metastasis. Cancer Metast. Rev. 2011, 30, 397-408. [CrossRef] [PubMed]

33. Zhou, Z.; Sun, C.; Tilley, S.L.; Mustafa, S.J. Mechanisms underlying uridine adenosine tetraphosphate-induced vascular contraction in mouse aorta: Role of thromboxane and purinergic receptors. Vasc. Pharmacol. 2015, 73, 78-85. [CrossRef] [PubMed]

34. Smith, W.L.; DeWitt, D.L.; Garavito, R.M. Cyclooxygenases: Structural, cellular, and molecular biology. Annu. Rev. Biochem. 2000, 69, 145-182. [CrossRef] [PubMed]

35. Davies, N.M.; Good, R.L.; Roupe, K.A.; Yanez, J.A. Cyclooxygenase-3: Axiom, dogma, anomaly, enigma or splice error?-Not as easy as 1, 2, 3. J. Pharm. Pharm. Sci. 2004, 7, 217-226. [PubMed]

36. Chandrasekharan, N.V.; Dai, H.; Roos, K.L.; Evanson, N.K.; Tomsik, J.; Elton, T.S.; Simmons, D.L. COX-3, a cyclooxygenase-1 variant inhibited by acetaminophen and other analgesic/antipyretic drugs: Cloning, structure, and expression. Proc. Natl. Acad. Sci. USA 2002, 99, 13926-13931. [CrossRef] [PubMed]

37. Schwab, J.M.; Beiter, T.; Linder, J.U.; Laufer, S.; Schulz, J.E.; Meyermann, R.; Schluesener, H.J. COX-3-A virtual pain target in humans? FASEB J. 2003, 17, 2174-2175. [CrossRef] [PubMed]

38. Willoughby, D.A.; Moore, A.R.; Colville-Nash, P.R. COX-1, COX-2, and COX-3 and the future treatment of chronic inflammatory disease. Lancet 2000, 355, 646-648. [CrossRef]

39. Radmark, O.; Werz, O.; Steinhilber, D.; Samuelsson, B. 5-Lipoxygenase, a key enzyme for leukotriene biosynthesis in health and disease. Biochim. Biophys. Acta 2015, 1851, 331-339. [CrossRef]

40. Mittal, M.; Kumar, R.B.; Balagunaseelan, N.; Hamberg, M.; Jegerschold, C.; Radmark, O.; Haeggstrom, J.Z.; Rinaldo-Matthis, A. Kinetic investigation of human 5-lipoxygenase with arachidonic acid. Bioorganic Med. Chem. Lett. 2016, 26, 3547-3551. [CrossRef]

41. Powell, W.S.; Gravelle, F.; Gravel, S. Metabolism of 5(S)-hydroxy-6,8,11,14-eicosatetraenoic acid and other 5(S)-hydroxyeicosanoids by a specific dehydrogenase in human polymorphonuclear leukocytes. J. Biol. Chem. 1992, 267, 19233-19241. [PubMed]

42. Mastyugin, V.; Aversa, E.; Bonazzi, A.; Vafaes, C.; Mieyal, P.; Schwartzman, M.L. Hypoxia-induced production of 12-hydroxyeicosanoids in the corneal epithelium: Involvement of a cytochrome P-4504B1 isoform. J. Pharmacol. Exp. Ther. 1999, 289, 1611-1619. [PubMed]

43. Powell, W.S.; Rokach, J. Biosynthesis, biological effects, and receptors of hydroxyeicosatetraenoic acids (HETEs) and oxoeicosatetraenoic acids (oxo-ETEs) derived from arachidonic acid. Biochim. Biophys. Acta 2015, 1851, 340-355. [CrossRef] [PubMed]

44. Shimizu, T.; Radmark, O.; Samuelsson, B. Enzyme with dual lipoxygenase activities catalyzes leukotriene A4 synthesis from arachidonic acid. Proc. Natl. Acad. Sci. USA 1984, 81, 689-693. [CrossRef] [PubMed]

45. Green, A.R.; Freedman, C.; Tena, J.; Tourdot, B.E.; Liu, B.; Holinstat, M.; Holman, T.R. 5 S,15 S-Dihydroperoxyeicosatetraenoic Acid (5,15-diHpETE) as a Lipoxin Intermediate: Reactivity and Kinetics with Human Leukocyte 5-Lipoxygenase, Platelet 12-Lipoxygenase, and Reticulocyte 15-Lipoxygenase-1. Biochemistry 2018, 57, 6726-6734. [CrossRef] [PubMed]

46. Nakao, A.; Watanabe, T.; Ohishi, N.; Toda, A.; Asano, K.; Taniguchi, S.; Nosaka, K.; Noiri, E.; Suzuki, T.; Sakai, T.; et al. Ubiquitous localization of leukotriene A4 hydrolase in the rat nephron. Kidney Int. 1999, 55, 100-108. [CrossRef] [PubMed] 
47. Baba, T.; Black, K.L.; Ikezaki, K.; Chen, K.N.; Becker, D.P. Intracarotid infusion of leukotriene C4 selectively increases blood-brain barrier permeability after focal ischemia in rats. J. Cereb. Blood Flow Metab. 1991, 11, 638-643. [CrossRef] [PubMed]

48. Porro, B.; Songia, P.; Squellerio, I.; Tremoli, E.; Cavalca, V. Analysis, physiological and clinical significance of 12-HETE: A neglected platelet-derived 12-lipoxygenase product. J. Chromatogr. B 2014, 964, 26-40. [CrossRef] [PubMed]

49. Witola, W.H.; Liu, S.R.; Montpetit, A.; Welti, R.; Hypolite, M.; Roth, M.; Zhou, Y.; Mui, E.; Cesbron-Delauw, M.F.; Fournie, G.J.; et al. ALOX12 in human toxoplasmosis. Infect. Immun. 2014, 82, 2670-2679. [CrossRef]

50. Serhan, C.N.; Sheppard, K.A. Lipoxin formation during human neutrophil-platelet interactions. Evidence for the transformation of leukotriene A4 by platelet 12-lipoxygenase in vitro. J. Clin. Investig. 1990, 85, 772-780. [CrossRef]

51. Fiore, S.; Ryeom, S.W.; Weller, P.F.; Serhan, C.N. Lipoxin recognition sites. Specific binding of labeled lipoxin A4 with human neutrophils. J. Biol. Chem. 1992, 267, 16168-16176. [PubMed]

52. Edenius, C.; Haeggstrom, J.; Lindgren, J.A. Transcellular conversion of endogenous arachidonic acid to lipoxins in mixed human platelet-granulocyte suspensions. Biochem. Biophys. Res. Commun. 1988, 157, 801-807. [CrossRef]

53. Sheppard, K.A.; Greenberg, S.M.; Funk, C.D.; Romano, M.; Serhan, C.N. Lipoxin generation by human megakaryocyte-induced 12-lipoxygenase. Biochim. Biophys. Acta 1992, 1133, 223-234. [CrossRef]

54. Moreno, J.J. New aspects of the role of hydroxyeicosatetraenoic acids in cell growth and cancer development. Biochem. Pharmacol. 2009, 77, 1-10. [CrossRef] [PubMed]

55. Medzhitov, R. Origin and physiological roles of inflammation. Nature 2008, 454, 428-435. [CrossRef] [PubMed]

56. Lasker, J.M.; Chen, W.B.; Wolf, I.; Bloswick, B.P.; Wilson, P.D.; Powell, P.K. Formation of 20-hydroxyeicosatetraenoic acid, a vasoactive and natriuretic eicosanoid, in human kidney. Role of Cyp4F2 and Cyp4A11. J. Biol. Chem. 2000, 275, 4118-4126. [CrossRef] [PubMed]

57. Wang, J.F.; Zhang, C.C.; Chou, K.C.; Wei, D.Q. Structure of cytochrome p450s and personalized drug. Curr. Med. Chem. 2009, 16, 232-244. [CrossRef]

58. Nebert, D.W.; Russell, D.W. Clinical importance of the cytochromes P450. Lancet 2002, 360, 1155-1162. [CrossRef]

59. Tacconelli, S.; Patrignani, P. Inside epoxyeicosatrienoic acids and cardiovascular disease. Front. Pharmacol. 2014, 5, 239. [CrossRef]

60. Aspromonte, N.; Monitillo, F.; Puzzovivo, A.; Valle, R.; Caldarola, P.; Iacoviello, M. Modulation of cardiac cytochrome P450 in patients with heart failure. Expert Opin. Drug Metab. Toxicol. 2014, 10,327-339. [CrossRef]

61. Shahabi, P.; Siest, G.; Visvikis-siest, S. Influence of inflammation on cardiovascular protective effects of cytochrome P450 epoxygenase-derived epoxyeicosatrienoic acids. Drug Metab. Rev. 2014, 46, 33-56. [CrossRef]

62. Alsaad, A.M.; Zordoky, B.N.; Tse, M.M.; El-Kadi, A.O. Role of cytochrome P450-mediated arachidonic acid metabolites in the pathogenesis of cardiac hypertrophy. Drug Metab. Rev. 2013, 45, 173-195. [CrossRef]

63. Bellien, J.; Joannides, R. Epoxyeicosatrienoic acid pathway in human health and diseases. J. Cardiovasc. Pharmacol. 2013, 61, 188-196. [CrossRef] [PubMed]

64. Makita, K.; Falck, J.R.; Capdevila, J.H. Cytochrome P450, the arachidonic acid cascade, and hypertension: New vistas for an old enzyme system. FASEB J. 1996, 10, 1456-1463. [CrossRef] [PubMed]

65. Zeldin, D.C.; DuBois, R.N.; Falck, J.R.; Capdevila, J.H. Molecular cloning, expression and characterization of an endogenous human cytochrome P450 arachidonic acid epoxygenase isoform. Arch. Biochem. Biophys. 1995, 322, 76-86. [CrossRef] [PubMed]

66. Luo, G.; Zeldin, D.C.; Blaisdell, J.A.; Hodgson, E.; Goldstein, J.A. Cloning and expression of murine CYP2Cs and their ability to metabolize arachidonic acid. Arch. Biochem. Biophys. 1998, 357, 45-57. [CrossRef]

67. Wu, S.; Moomaw, C.R.; Tomer, K.B.; Falck, J.R.; Zeldin, D.C. Molecular cloning and expression of CYP2J2, a human cytochrome P450 arachidonic acid epoxygenase highly expressed in heart. J. Biol. Chem. 1996, 271, 3460-3468. [CrossRef] 
68. Ma, J.; Qu, W.; Scarborough, P.E.; Tomer, K.B.; Moomaw, C.R.; Maronpot, R.; Davis, L.S.; Breyer, M.D.; Zeldin, D.C. Molecular cloning, enzymatic characterization, developmental expression, and cellular localization of a mouse cytochrome P450 highly expressed in kidney. J. Biol. Chem. 1999, 274, 17777-17788. [CrossRef]

69. Zhao, X.; Imig, J.D. Kidney CYP450 enzymes: Biological actions beyond drug metabolism. Curr. Drug Metab. 2003, 4, 73-84. [CrossRef]

70. Yu, Z.; Xu, F.; Huse, L.M.; Morisseau, C.; Draper, A.J.; Newman, J.W.; Parker, C.; Graham, L.; Engler, M.M.; Hammock, B.D.; et al. Soluble epoxide hydrolase regulates hydrolysis of vasoactive epoxyeicosatrienoic acids. Circ. Res. 2000, 87, 992-998. [CrossRef]

71. Quigley, R.; Baum, M.; Reddy, K.M.; Griener, J.C.; Falck, J.R. Effects of 20-HETE and 19(S)-HETE on rabbit proximal straight tubule volume transport. Am. J. Physiol. Ren. Physiol. 2000, 278, F949-F953. [CrossRef] [PubMed]

72. Snider, N.T.; Kornilov, A.M.; Kent, U.M.; Hollenberg, P.F. Anandamide metabolism by human liver and kidney microsomal cytochrome p450 enzymes to form hydroxyeicosatetraenoic and epoxyeicosatrienoic acid ethanolamides. J. Pharmacol. Exp. Ther. 2007, 321, 590-597. [CrossRef] [PubMed]

73. Collins, X.H.; Harmon, S.D.; Kaduce, T.L.; Berst, K.B.; Fang, X.; Moore, S.A.; Raju, T.V.; Falck, J.R.; Weintraub, N.L.; Duester, G.; et al. Omega-oxidation of 20-hydroxyeicosatetraenoic acid (20-HETE) in cerebral microvascular smooth muscle and endothelium by alcohol dehydrogenase 4. J. Biol. Chem. 2005, 280, 33157-33164. [CrossRef] [PubMed]

74. Nguyen, X.; Wang, M.H.; Reddy, K.M.; Falck, J.R.; Schwartzman, M.L. Kinetic profile of the rat CYP4A isoforms: Arachidonic acid metabolism and isoform-specific inhibitors. Am. J. Physiol. 1999, 276, R1691-R1700. [CrossRef] [PubMed]

75. Gupta, R.; Yadav, A.; Misra, R.; Aggarwal, A. Urinary prostaglandin D synthase as biomarker in lupus nephritis: A longitudinal study. Clin. Exp. Rheumatol. 2015, 33, 694-698. [PubMed]

76. Somparn, P.; Hirankarn, N.; Leelahavanichkul, A.; Khovidhunkit, W.; Thongboonkerd, V.; Avihingsanon, Y. Urinary proteomics revealed prostaglandin $\mathrm{H}(2) \mathrm{D}$-isomerase, not Zn-alpha2-glycoprotein, as a biomarker for active lupus nephritis. J. Proteom. 2012, 75, 3240-3247. [CrossRef] [PubMed]

77. Smith, E.M.D.; Eleuteri, A.; Goilav, B.; Lewandowski, L.; Phuti, A.; Rubinstein, T.; Wahezi, D.; Jones, C.A.; Marks, S.D.; Corkhill, R.; et al. A Markov Multi-State model of lupus nephritis urine biomarker panel dynamics in children: Predicting changes in disease activity. Clin. Immunol. 2019, 198, 71-78. [CrossRef] [PubMed]

78. Pellefigues, C.; Dema, B.; Lamri, Y.; Saidoune, F.; Chavarot, N.; Loheac, C.; Pacreau, E.; Dussiot, M.; Bidault, C.; Marquet, F.; et al. Prostaglandin D2 amplifies lupus disease through basophil accumulation in lymphoid organs. Nat. Commun. 2018, 9, 725. [CrossRef]

79. Pettipher, R.; Hansel, T.T.; Armer, R. Antagonism of the prostaglandin D2 receptors DP1 and CRTH2 as an approach to treat allergic diseases. Nat. Rev. Drug Discov. 2007, 6, 313-325. [CrossRef]

80. Rajakariar, R.; Hilliard, M.; Lawrence, T.; Trivedi, S.; Colville-Nash, P.; Bellingan, G.; Fitzgerald, D.; Yaqoob, M.M.; Gilroy, D.W. Hematopoietic prostaglandin D2 synthase controls the onset and resolution of acute inflammation through PGD2 and 15-deoxyDelta12 14 PGJ2. Proc. Natl. Acad. Sci. USA 2007, 104, 20979-20984. [CrossRef]

81. Hirai, H.; Tanaka, K.; Yoshie, O.; Ogawa, K.; Kenmotsu, K.; Takamori, Y.; Ichimasa, M.; Sugamura, K.; Nakamura, M.; Takano, S.; et al. Prostaglandin D2 selectively induces chemotaxis in T helper type 2 cells, eosinophils, and basophils via seven-transmembrane receptor CRTH2. J. Exp. Med. 2001, 193, 255-261. [CrossRef] [PubMed]

82. Togel, F.; Isaac, J.; Hu, Z.; Weiss, K.; Westenfelder, C. Renal SDF-1 signals mobilization and homing of CXCR4-positive cells to the kidney after ischemic injury. Kidney Int. 2005, 67, 1772-1784. [CrossRef] [PubMed]

83. Devi, S.; Wang, Y.; Chew, W.K.; Lima, R.; Gonzalez, N.A.; Mattar, C.N.; Chong, S.Z.; Schlitzer, A.; Bakocevic, N.; Chew, S.; et al. Neutrophil mobilization via plerixafor-mediated CXCR4 inhibition arises from lung demargination and blockade of neutrophil homing to the bone marrow. J. Exp. Med. 2013, 210, 2321-2336. [CrossRef] [PubMed] 
84. Daza, L.; Kornhauser, C.; Zamora, L.; Flores, J. Captopril effect on prostaglandin E2, thromboxane B2 and proteinuria in lupus nephritis patients. Prostaglandins Other Lipid Mediat. 2005, 78, 194-201. [CrossRef] [PubMed]

85. Ito, H.; Yan, X.; Nagata, N.; Aritake, K.; Katsumata, Y.; Matsuhashi, T.; Nakamura, M.; Hirai, H.; Urade, Y.; Asano, K.; et al. PGD2-CRTH2 pathway promotes tubulointerstitial fibrosis. J. Am. Soc. Nephrol. 2012, 23, 1797-1809. [CrossRef] [PubMed]

86. Lu, Y.; Zhou, Q.; Zhong, F.; Guo, S.; Hao, X.; Li, C.; Wang, W.; Chen, N. 15-Deoxy-Delta(12,14)-prostaglandin $\mathrm{J}(2)$ modulates lipopolysaccharide-induced chemokine expression by blocking nuclear factor-kappaB activation via peroxisome proliferator activated receptor-gamma-independent mechanism in renal tubular epithelial cells. Nephron Exp. Nephrol. 2013, 123, 1-10. [CrossRef] [PubMed]

87. Hart, D.; Lifschitz, M.D. Renal physiology of the prostaglandins and the effects of nonsteroidal anti-inflammatory agents on the kidney. Am. J. Nephrol. 1987, 7, 408-418. [CrossRef]

88. Dunn, M.J.; Hood, V.L. Prostaglandins and the kidney. Am. J. Physiol. 1977, 233, 169-184. [CrossRef]

89. Nasrallah, R.; Hassouneh, R.; Hebert, R.L. Chronic kidney disease: Targeting prostaglandin E2 receptors. Am. J. Physiol. Ren. Physiol. 2014, 307, F243-F250. [CrossRef]

90. Breyer, M.D.; Breyer, R.M. Prostaglandin E receptors and the kidney. Am. J. Physiol. Ren. Physiol. 2000, 279, F12-F23. [CrossRef]

91. Kotnik, P.; Nielsen, J.; Kwon, T.H.; Krzisnik, C.; Frokiaer, J.; Nielsen, S. Altered expression of COX-1, COX-2, and mPGES in rats with nephrogenic and central diabetes insipidus. Am. J. Physiol. Ren. Physiol. 2005, 288, F1053-F1068. [CrossRef] [PubMed]

92. Sanchez, T.; Moreno, J.J. Role of EP(1) and EP(4) PGE(2) subtype receptors in serum-induced 3T6 fibroblast cycle progression and proliferation. Am. J. Physiol. Cell Physiol. 2002, 282, C280-C288. [CrossRef] [PubMed]

93. Moore, B.B.; Ballinger, M.N.; White, E.S.; Green, M.E.; Herrygers, A.B.; Wilke, C.A.; Toews, G.B.; Peters-Golden, M. Bleomycin-induced E prostanoid receptor changes alter fibroblast responses to prostaglandin E2. J. Immunol. 2005, 174, 5644-5649. [CrossRef] [PubMed]

94. Yokoyama, U.; Iwatsubo, K.; Umemura, M.; Fujita, T.; Ishikawa, Y. The prostanoid EP4 receptor and its signaling pathway. Pharmacol. Rev. 2013, 65, 1010-1052. [CrossRef] [PubMed]

95. Breyer, M.D.; Davis, L.; Jacobson, H.R.; Breyer, R.M. Differential localization of prostaglandin E receptor subtypes in human kidney. Am. J. Physiol. 1996, 270, F912-F918. [CrossRef] [PubMed]

96. Thibodeau, J.F.; Nasrallah, R.; Carter, A.; He, Y.; Touyz, R.; Hebert, R.L.; Kennedy, C.R.J. PTGER1 deletion attenuates renal injury in diabetic mouse models. Am. J. Pathol. 2013, 183, 1789-1802. [CrossRef]

97. Rahal, S.; McVeigh, L.I.; Zhang, Y.; Guan, Y.; Breyer, M.D.; Kennedy, C.R. Increased severity of renal impairment in nephritic mice lacking the EP1 receptor. Can. J. Physiol. Pharmacol. 2006, 84, 877-885. [CrossRef]

98. Tang, L.; Loutzenhiser, K.; Loutzenhiser, R. Biphasic actions of prostaglandin E(2) on the renal afferent arteriole: Role of EP(3) and EP(4) receptors. Circ. Res. 2000, 86, 663-670. [CrossRef]

99. Srivastava, T.; Alon, U.S.; Cudmore, P.A.; Tarakji, B.; Kats, A.; Garola, R.E.; Duncan, R.S.; McCarthy, E.T.; Sharma, R.; Johnson, M.L.; et al. Cyclooxygenase-2, prostaglandin E2, and prostanoid receptor EP2 in fluid flow shear stress-mediated injury in the solitary kidney. Am. J. Physiol. Ren. Physiol. 2014, 307, F1323-F1333. [CrossRef]

100. Mohamed, R.; Jayakumar, C.; Ranganathan, P.V.; Ganapathy, V.; Ramesh, G. Kidney proximal tubular epithelial-specific overexpression of netrin-1 suppresses inflammation and albuminuria through suppression of COX-2-mediated PGE2 production in streptozotocin-induced diabetic mice. Am. J. Pathol. 2012, 181, 1991-2002. [CrossRef]

101. Hassouneh, R.; Nasrallah, R.; Zimpelmann, J.; Gutsol, A.; Eckert, D.; Ghossein, J.; Burns, K.D.; Hebert, R.L. PGE2 receptor EP3 inhibits water reabsorption and contributes to polyuria and kidney injury in a streptozotocin-induced mouse model of diabetes. Diabetologia 2016, 59, 1318-1328. [CrossRef] [PubMed]

102. Frolich, S.; Olliges, A.; Kern, N.; Schreiber, Y.; Narumiya, S.; Nusing, R.M. Temporal expression of the PGE2 synthetic system in the kidney is associated with the time frame of renal developmental vulnerability to cyclooxygenase-2 inhibition. Am. J. Physiol. Ren. Physiol. 2012, 303, F209-F219. [CrossRef] [PubMed]

103. Nakagawa, N.; Yuhki, K.; Kawabe, J.; Fujino, T.; Takahata, O.; Kabara, M.; Abe, K.; Kojima, F.; Kashiwagi, H.; Hasebe, N.; et al. The intrinsic prostaglandin E2-EP4 system of the renal tubular epithelium limits the development of tubulointerstitial fibrosis in mice. Kidney Int. 2012, 82, 158-171. [CrossRef] [PubMed] 
104. Fujino, H.; Xu, W.; Regan, J.W. Prostaglandin E2 induced functional expression of early growth response factor-1 by EP4, but not EP2, prostanoid receptors via the phosphatidylinositol 3-kinase and extracellular signal-regulated kinases. J. Biol. Chem. 2003, 278, 12151-12156. [CrossRef] [PubMed]

105. Faour, W.H.; Gomi, K.; Kennedy, C.R. PGE(2) induces COX-2 expression in podocytes via the EP(4) receptor through a PKA-independent mechanism. Cell Signal. 2008, 20, 2156-2164. [CrossRef] [PubMed]

106. Jensen, B.L.; Mann, B.; Skott, O.; Kurtz, A. Differential regulation of renal prostaglandin receptor mRNAs by dietary salt intake in the rat. Kidney Int. 1999, 56, 528-537. [CrossRef] [PubMed]

107. Stitt-Cavanagh, E.M.; Faour, W.H.; Takami, K.; Carter, A.; Vanderhyden, B.; Guan, Y.; Schneider, A.; Breyer, M.D.; Kennedy, C.R. A maladaptive role for EP4 receptors in podocytes. J. Am. Soc. Nephrol. 2010, 21, 1678-1690. [CrossRef] [PubMed]

108. Yamamoto, E.; Izawa, T.; Juniantito, V.; Kuwamura, M.; Sugiura, K.; Takeuchi, T.; Yamate, J. Involvement of endogenous prostaglandin E2 in tubular epithelial regeneration through inhibition of apoptosis and epithelial-mesenchymal transition in cisplatin-induced rat renal lesions. Histol. Histopathol. 2010, 25, 995-1007. [CrossRef]

109. Vukicevic, S.; Simic, P.; Borovecki, F.; Grgurevic, L.; Rogic, D.; Orlic, I.; Grasser, W.A.; Thompson, D.D.; Paralkar, V.M. Role of EP2 and EP4 receptor-selective agonists of prostaglandin E(2) in acute and chronic kidney failure. Kidney Int. 2006, 70, 1099-1106. [CrossRef]

110. Mohamed, R.; Jayakumar, C.; Ramesh, G. Chronic administration of EP4-selective agonist exacerbates albuminuria and fibrosis of the kidney in streptozotocin-induced diabetic mice through IL-6. Lab. Investig. 2013, 93, 933-945. [CrossRef]

111. Chang, J.; Blazek, E.; Kreft, A.F.; Lewis, A.J. Inhibition of platelet and neutrophil phospholipase A2 by hydroxyeicosatetraenoic acids (HETES). A novel pharmacological mechanism for regulating free fatty acid release. Biochem. Pharmacol. 1985, 34, 1571-1575. [CrossRef]

112. Johnson, E.N.; Brass, L.F.; Funk, C.D. Increased platelet sensitivity to ADP in mice lacking platelet-type 12-lipoxygenase. Proc. Natl. Acad. Sci. USA 1998, 95, 3100-3105. [CrossRef] [PubMed]

113. Coulon, L.; Calzada, C.; Moulin, P.; Vericel, E.; Lagarde, M. Activation of p38 mitogen-activated protein kinase/cytosolic phospholipase A2 cascade in hydroperoxide-stressed platelets. Free Radic. Biol. Med. 2003, 35, 616-625. [CrossRef]

114. Jansen, M.P.; Emal, D.; Teske, G.J.; Dessing, M.C.; Florquin, S.; Roelofs, J.J. Release of extracellular DNA influences renal ischemia reperfusion injury by platelet activation and formation of neutrophil extracellular traps. Kidney Int. 2017, 91, 352-364. [CrossRef] [PubMed]

115. Fajas, L.; Auboeuf, D.; Raspe, E.; Schoonjans, K.; Lefebvre, A.M.; Saladin, R.; Najib, J.; Laville, M.; Fruchart, J.C.; Deeb, S.; et al. The organization, promoter analysis, and expression of the human PPARgamma gene. J. Biol. Chem. 1997, 272, 18779-18789. [CrossRef] [PubMed]

116. Berger, J.P.; Akiyama, T.E.; Meinke, P.T. PPARs: Therapeutic targets for metabolic disease. Trends Pharmacol. Sci. 2005, 26, 244-251. [CrossRef] [PubMed]

117. Platt, C.; Coward, R.J. Peroxisome proliferator activating receptor-gamma and the podocyte. Nephrol. Dial. Transplant. 2017, 32, 423-433. [CrossRef]

118. Nagy, L.; Tontonoz, P.; Alvarez, J.G.; Chen, H.; Evans, R.M. Oxidized LDL regulates macrophage gene expression through ligand activation of PPARgamma. Cell 1998, 93, 229-240. [CrossRef]

119. Huang, J.T.; Welch, J.S.; Ricote, M.; Binder, C.J.; Willson, T.M.; Kelly, C.; Witztum, J.L.; Funk, C.D.; Conrad, D.; Glass, C.K. Interleukin-4-dependent production of PPAR-gamma ligands in macrophages by 12/15-lipoxygenase. Nature 1999, 400, 378-382. [CrossRef]

120. Okamura, D.M.; Lopez-Guisa, J.M.; Koelsch, K.; Collins, S.; Eddy, A.A. Atherogenic scavenger receptor modulation in the tubulointerstitium in response to chronic renal injury. Am. J. Physiol. Ren. Physiol. 2007, 293, F575-F585. [CrossRef]

121. Fruchart, J.C. Peroxisome proliferator-activated receptor-alpha (PPARalpha): At the crossroads of obesity, diabetes and cardiovascular disease. Atherosclerosis 2009, 205, 1-8. [CrossRef] [PubMed]

122. Tanaka, Y.; Kume, S.; Araki, S.; Isshiki, K.; Chin-Kanasaki, M.; Sakaguchi, M.; Sugimoto, T.; Koya, D.; Haneda, M.; Kashiwagi, A.; et al. Fenofibrate, a PPARalpha agonist, has renoprotective effects in mice by enhancing renal lipolysis. Kidney Int. 2011, 79, 871-882. [CrossRef] [PubMed]

123. Stadler, K.; Goldberg, I.J.; Susztak, K. The evolving understanding of the contribution of lipid metabolism to diabetic kidney disease. Curr. Diabetes Rep. 2015, 15, 40. [CrossRef] [PubMed] 
124. Fan, F.; Muroya, Y.; Roman, R.J. Cytochrome P450 eicosanoids in hypertension and renal disease. Curr. Opin. Nephrol. Hypertens. 2015, 24, 37-46. [CrossRef] [PubMed]

125. Croft, K.D.; McGiff, J.C.; Sanchez-Mendoza, A.; Carroll, M.A. Angiotensin II releases 20-HETE from rat renal microvessels. Am. J. Physiol. Ren. Physiol. 2000, 279, F544-F551. [CrossRef] [PubMed]

126. Parmentier, J.H.; Muthalif, M.M.; Saeed, A.E.; Malik, K.U. Phospholipase D activation by norepinephrine is mediated by 12(s)-, 15(s)-, and 20-hydroxyeicosatetraenoic acids generated by stimulation of cytosolic phospholipase a2. Tyrosine phosphorylation of phospholipase d2 in response to norepinephrine. J. Biol. Chem. 2001, 276, 15704-15711. [CrossRef] [PubMed]

127. Escalante, B.; Erlij, D.; Falck, J.R.; McGiff, J.C. Effect of cytochrome P450 arachidonate metabolites on ion transport in rabbit kidney loop of Henle. Science 1991, 251, 799-802. [CrossRef]

128. Capdevila, J.H.; Falck, J.R. The CYP P450 arachidonic acid monooxygenases: From cell signaling to blood pressure regulation. Biochem. Biophys. Res. Commun. 2001, 285, 571-576. [CrossRef]

129. Williams, J.M.; Fan, F.; Murphy, S.; Schreck, C.; Lazar, J.; Jacob, H.J.; Roman, R.J. Role of 20-HETE in the antihypertensive effect of transfer of chromosome 5 from Brown Norway to Dahl salt-sensitive rats. Am. J. Physiol. Regul. Integr. Comp. Physiol. 2012, 302, R1209-R1218. [CrossRef]

130. Williams, J.M.; Sarkis, A.; Hoagland, K.M.; Fredrich, K.; Ryan, R.P.; Moreno, C.; Lopez, B.; Lazar, J.; Fenoy, F.J.; Sharma, M.; et al. Transfer of the CYP4A region of chromosome 5 from Lewis to Dahl S rats attenuates renal injury. Am. J. Physiol. Ren. Physiol. 2008, 295, F1764-F1777. [CrossRef]

131. Dahly-Vernon, A.J.; Sharma, M.; McCarthy, E.T.; Savin, V.J.; Ledbetter, S.R.; Roman, R.J. Transforming growth factor-beta, 20-HETE interaction, and glomerular injury in Dahl salt-sensitive rats. Hypertension 2005, 45, 643-648. [CrossRef] [PubMed]

132. Roman, R.J.; Ma, Y.H.; Frohlich, B.; Markham, B. Clofibrate prevents the development of hypertension in Dahl salt-sensitive rats. Hypertension 1993, 21, 985-988. [CrossRef] [PubMed]

133. Ma, Y.H.; Schwartzman, M.L.; Roman, R.J. Altered renal P-450 metabolism of arachidonic acid in Dahl salt-sensitive rats. Am. J. Physiol. 1994, 267, R579-R589. [CrossRef] [PubMed]

134. Moreno, C.; Maier, K.G.; Hoagland, K.M.; Yu, M.; Roman, R.J. Abnormal pressure-natriuresis in hypertension: Role of cytochrome P450 metabolites of arachidonic acid. Am. J. Hypertens. 2001, 14, 90S-97S. [CrossRef]

135. Alonso-Galicia, M.; Maier, K.G.; Greene, A.S.; Cowley, A.W., Jr.; Roman, R.J. Role of 20-hydroxyeicosatetraenoic acid in the renal and vasoconstrictor actions of angiotensin II. Am. J. Physiol. Regul. Integr. Comp. Physiol. 2002, 283, R60-R68. [CrossRef] [PubMed]

136. McGiff, J.C.; Quilley, J. 20-HETE and the kidney: Resolution of old problems and new beginnings. Am. J. Physiol. 1999, 277, R607-R623. [CrossRef] [PubMed]

137. Roman, R.J. P-450 metabolites of arachidonic acid in the control of cardiovascular function. Physiol. Rev. 2002, 82, 131-185. [CrossRef]

138. Williams, J.M.; Sarkis, A.; Lopez, B.; Ryan, R.P.; Flasch, A.K.; Roman, R.J. Elevations in renal interstitial hydrostatic pressure and 20-hydroxyeicosatetraenoic acid contribute to pressure natriuresis. Hypertension 2007, 49, 687-694. [CrossRef]

139. Williams, J.M.; Murphy, S.; Burke, M.; Roman, R.J. 20-hydroxyeicosatetraeonic acid: A new target for the treatment of hypertension. J. Cardiovasc. Pharmacol. 2010, 56, 336-344. [CrossRef]

140. Nilakantan, V.; Maenpaa, C.; Jia, G.; Roman, R.J.; Park, F. 20-HETE-mediated cytotoxicity and apoptosis in ischemic kidney epithelial cells. Am. J. Physiol. Ren. Physiol. 2008, 294, F562-F570. [CrossRef]

141. Lameire, N.; Vanholder, R. Pathophysiologic features and prevention of human and experimental acute tubular necrosis. J. Am. Soc. Nephrol. 2001, 12 (Suppl. 17), S20-S32.

142. Fan, F.; Ge, Y.; Lv, W.; Elliott, M.R.; Muroya, Y.; Hirata, T.; Booz, G.W.; Roman, R.J. Molecular mechanisms and cell signaling of 20-hydroxyeicosatetraenoic acid in vascular pathophysiology. Front. Biosci. 2016, $21,1427-1463$.

143. Regner, K.R.; Zuk, A.; Van Why, S.K.; Shames, B.D.; Ryan, R.P.; Falck, J.R.; Manthati, V.L.; McMullen, M.E.; Ledbetter, S.R.; Roman, R.J. Protective effect of 20-HETE analogues in experimental renal ischemia reperfusion injury. Kidney Int. 2009, 75, 511-517. [CrossRef] [PubMed]

144. Roman, R.J.; Akbulut, T.; Park, F.; Regner, K.R. 20-HETE in acute kidney injury. Kidney Int. 2011, 79, 10-13. [CrossRef] 
145. Eid, A.A.; Gorin, Y.; Fagg, B.M.; Maalouf, R.; Barnes, J.L.; Block, K.; Abboud, H.E. Mechanisms of podocyte injury in diabetes: Role of cytochrome P450 and NADPH oxidases. Diabetes 2009, 58, 1201-1211. [CrossRef] [PubMed]

146. Eid, S.; Maalouf, R.; Jaffa, A.A.; Nassif, J.; Hamdy, A.; Rashid, A.; Ziyadeh, F.N.; Eid, A.A. 20-HETE and EETs in diabetic nephropathy: A novel mechanistic pathway. PLoS ONE 2013, 8, e70029. [CrossRef] [PubMed]

147. Roshanravan, H.; Kim, E.Y.; Dryer, S.E. 20-Hydroxyeicosatetraenoic Acid (20-HETE) Modulates Canonical Transient Receptor Potential-6 (TRPC6) Channels in Podocytes. Front. Physiol. 2016, 7, 351. [CrossRef]

148. Kriz, W.; Lemley, K.V. A potential role for mechanical forces in the detachment of podocytes and the progression of CKD. J. Am. Soc. Nephrol. 2015, 26, 258-269. [CrossRef]

149. Omata, K.; Tsutsumi, E.; Sheu, H.L.; Utsumi, Y.; Abe, K. Effect of aging on renal cytochrome P450-dependent arachidonic acid metabolism in Dahl rats. J. Lipid Mediat. 1993, 6, 369-373. [PubMed]

150. Moore, K.P.; Wood, J.; Gove, C.; Tan, K.C.; Eason, J.; Taylor, G.W.; Williams, R. Synthesis and metabolism of cysteinyl leukotrienes by the isolated pig kidney. Adv. Prostaglandin Thromboxane Leukot. Res. 1991, 21B, 697-700. [CrossRef] [PubMed]

151. Klausner, J.M.; Paterson, I.S.; Goldman, G.; Kobzik, L.; Rodzen, C.; Lawrence, R.; Valeri, C.R.; Shepro, D.; Hechtman, H.B. Postischemic renal injury is mediated by neutrophils and leukotrienes. Am. J. Physiol. 1989, 256, F794-F802. [CrossRef] [PubMed]

152. Sener, G.; Sakarcan, A.; Sehirli, O.; Eksioglu-Demiralp, E.; Sener, E.; Ercan, F.; Gedik, N.; Yegen, B.C. Chronic renal failure-induced multiple-organ injury in rats is alleviated by the selective CysLT1 receptor antagonist montelukast. Prostaglandins Other Lipid Mediat. 2007, 83, 257-267. [CrossRef] [PubMed]

153. Noiri, E.; Yokomizo, T.; Nakao, A.; Izumi, T.; Fujita, T.; Kimura, S.; Shimizu, T. An in vivo approach showing the chemotactic activity of leukotriene $\mathrm{B}(4)$ in acute renal ischemic-reperfusion injury. Proc. Natl. Acad. Sci. USA 2000, 97, 823-828. [CrossRef] [PubMed]

154. Landgraf, S.S.; Silva, L.S.; Peruchetti, D.B.; Sirtoli, G.M.; Moraes-Santos, F.; Portella, V.G.; Silva-Filho, J.L.; Pinheiro, C.S.; Abreu, T.P.; Takiya, C.M.; et al. 5-Lypoxygenase products are involved in renal tubulointerstitial injury induced by albumin overload in proximal tubules in mice. PLoS ONE 2014, 9, e107549. [CrossRef] [PubMed]

155. Zimmerman, G.A.; McIntyre, T.M. Neutrophil adherence to human endothelium in vitro occurs by CDw 18 (Mo1, MAC-1/LFA-1/GP 150,95) glycoprotein-dependent and -independent mechanisms. J. Clin. Investig. 1988, 81, 531-537. [CrossRef] [PubMed]

156. Yared, A.; Albrightson-Winslow, C.; Griswold, D.; Takahashi, K.; Fogo, A.; Badr, K.F. Functional significance of leukotriene B4 in normal and glomerulonephritic kidneys. J. Am. Soc. Nephrol. 1991, 2, 45-56. [PubMed]

157. Zedan, M.M.; El-Refaey, A.; Zaghloul, H.; Abdelrahim, M.E.; Osman, A.; Zedan, M.M.; Eltantawy, N. Montelukast as an add-on treatment in steroid dependant nephrotic syndrome, randomised-controlled trial. J. Nephrol. 2016, 29, 585-592. [CrossRef]

158. Planaguma, A.; Kazani, S.; Marigowda, G.; Haworth, O.; Mariani, T.J.; Israel, E.; Bleecker, E.R.; Curran-Everett, D.; Erzurum, S.C.; Calhoun, W.J.; et al. Airway lipoxin A4 generation and lipoxin A4 receptor expression are decreased in severe asthma. Am. J. Respir. Crit. Care Med. 2008, 178, 574-582. [CrossRef]

159. Cheng, X.; He, S.; Yuan, J.; Miao, S.; Gao, H.; Zhang, J.; Li, Y.; Peng, W.; Wu, P. Lipoxin A4 attenuates LPS-induced mouse acute lung injury via Nrf2-mediated E-cadherin expression in airway epithelial cells. Free Radic. Biol. Med. 2016, 93, 52-66. [CrossRef]

160. Kieran, N.E.; Maderna, P.; Godson, C. Lipoxins: Potential anti-inflammatory, proresolution, and antifibrotic mediators in renal disease. Kidney Int. 2004, 65, 1145-1154. [CrossRef]

161. Christie, P.E.; Spur, B.W.; Lee, T.H. The effects of lipoxin A4 on airway responses in asthmatic subjects. Am. Rev. Respir. Dis. 1992, 145, 1281-1284. [CrossRef] [PubMed]

162. Dahlen, S.E.; Franzen, L.; Raud, J.; Serhan, C.N.; Westlund, P.; Wikstrom, E.; Bjorck, T.; Matsuda, H.; Webber, S.E.; Veale, C.A.; et al. Actions of lipoxin A4 and related compounds in smooth muscle preparations and on the microcirculation in vivo. Adv. Exp. Med. Biol. 1988, 229, 107-130. [PubMed]

163. Wu, S.H.; Liao, P.Y.; Yin, P.L.; Zhang, Y.M.; Dong, L. Elevated expressions of 15-lipoxygenase and lipoxin A4 in children with acute poststreptococcal glomerulonephritis. Am. J. Pathol. 2009, 174, 115-122. [CrossRef] [PubMed] 
164. Rodgers, K.; McMahon, B.; Mitchell, D.; Sadlier, D.; Godson, C. Lipoxin A4 modifies platelet-derived growth factor-induced pro-fibrotic gene expression in human renal mesangial cells. Am. J. Pathol. 2005, 167, 683-694. [CrossRef]

165. O'Meara, Y.M.; Brady, H.R. Lipoxins, leukocyte recruitment and the resolution phase of acute glomerulonephritis. Kidney Int. Suppl. 1997, 58, S56-S61. [PubMed]

166. Munger, K.A.; Montero, A.; Fukunaga, M.; Uda, S.; Yura, T.; Imai, E.; Kaneda, Y.; Valdivielso, J.M.; Badr, K.F. Transfection of rat kidney with human 15-lipoxygenase suppresses inflammation and preserves function in experimental glomerulonephritis. Proc. Natl. Acad. Sci. USA 1999, 96, 13375-13380. [CrossRef] [PubMed]

167. Davin, J.C.; Coppo, R. Henoch-Schonlein purpura nephritis in children. Nat. Rev. Nephrol. 2014, 10, 563-573. [CrossRef] [PubMed]

168. Borgeson, E.; Docherty, N.G.; Murphy, M.; Rodgers, K.; Ryan, A.; O'Sullivan, T.P.; Guiry, P.J.; Goldschmeding, R.; Higgins, D.F.; Godson, C. Lipoxin A(4) and benzo-lipoxin A(4) attenuate experimental renal fibrosis. FASEB J. 2011, 25, 2967-2979. [CrossRef]

169. Borgeson, E.; Johnson, A.M.; Lee, Y.S.; Till, A.; Syed, G.H.; Ali-Shah, S.T.; Guiry, P.J.; Dalli, J.; Colas, R.A.; Serhan, C.N.; et al. Lipoxin A4 Attenuates Obesity-Induced Adipose Inflammation and Associated Liver and Kidney Disease. Cell Metab. 2015, 22, 125-137. [CrossRef]

170. Brennan, E.P.; Mohan, M.; McClelland, A.; Tikellis, C.; Ziemann, M.; Kaspi, A.; Gray, S.P.; Pickering, R.; Tan, S.M.; Ali-Shah, S.T.; et al. Lipoxins Regulate the Early Growth Response-1 Network and Reverse Diabetic Kidney Disease. J. Am. Soc. Nephrol. 2018, 29, 1437-1448. [CrossRef]

171. Sun, S.; Ning, X.; Zhai, Y.; Du, R.; Lu, Y.; He, L.; Li, R.; Wu, W.; Sun, W.; Wang, H. Egr-1 mediates chronic hypoxia-induced renal interstitial fibrosis via the PKC/ERK pathway. Am. J. Nephrol. 2014, 39, 436-448. [CrossRef] [PubMed]

172. McMahon, B.; Stenson, C.; McPhillips, F.; Fanning, A.; Brady, H.R.; Godson, C. Lipoxin A4 antagonizes the mitogenic effects of leukotriene D4 in human renal mesangial cells. Differential activation of MAP kinases through distinct receptors. J. Biol. Chem. 2000, 275, 27566-27575. [CrossRef] [PubMed]

173. Ho, L.C.; Sung, J.M.; Shen, Y.T.; Jheng, H.F.; Chen, S.H.; Tsai, P.J.; Tsai, Y.S. Egr-1 deficiency protects from renal inflammation and fibrosis. J. Mol. Med. 2016, 94, 933-942. [CrossRef] [PubMed]

174. Yeboah, M.M.; Hye Khan, M.A.; Chesnik, M.A.; Sharma, A.; Paudyal, M.P.; Falck, J.R.; Imig, J.D. The epoxyeicosatrienoic acid analog PVPA ameliorates cyclosporine-induced hypertension and renal injury in rats. Am. J. Physiol. Ren. Physiol. 2016, 311, F576-F585. [CrossRef] [PubMed]

175. Kim, J.; Imig, J.D.; Yang, J.; Hammock, B.D.; Padanilam, B.J. Inhibition of soluble epoxide hydrolase prevents renal interstitial fibrosis and inflammation. Am. J. Physiol. Ren. Physiol. 2014, 307, F971-F980. [CrossRef]

176. Manhiani, M.; Quigley, J.E.; Knight, S.F.; Tasoobshirazi, S.; Moore, T.; Brands, M.W.; Hammock, B.D.; Imig, J.D. Soluble epoxide hydrolase gene deletion attenuates renal injury and inflammation with DOCA-salt hypertension. Am. J. Physiol. Ren. Physiol. 2009, 297, F740-F748. [CrossRef] [PubMed]

177. Roche, C.; Guerrot, D.; Harouki, N.; Duflot, T.; Besnier, M.; Remy-Jouet, I.; Renet, S.; Dumesnil, A.; Lejeune, A.; Morisseau, C.; et al. Impact of soluble epoxide hydrolase inhibition on early kidney damage in hyperglycemic overweight mice. Prostaglandins Other Lipid Mediat. 2015, 120, 148-154. [CrossRef]

178. Zhu, Y.; Blum, M.; Hoff, U.; Wesser, T.; Fechner, M.; Westphal, C.; Gurgen, D.; Catar, R.A.; Philippe, A.; $\mathrm{Wu}, \mathrm{K}$; et al. Renal Ischemia/Reperfusion Injury in Soluble Epoxide Hydrolase-Deficient Mice. PLoS ONE 2016, 11, e0145645. [CrossRef]

179. Hercule, H.C.; Schunck, W.H.; Gross, V.; Seringer, J.; Leung, F.P.; Weldon, S.M.; da Costa Goncalves, A.; Huang, Y.; Luft, F.C.; Gollasch, M. Interaction between P450 eicosanoids and nitric oxide in the control of arterial tone in mice. Arterioscler. Thromb. Vasc. Biol. 2009, 29, 54-60. [CrossRef]

180. Deng, B.Q.; Luo, Y.; Kang, X.; Li, C.B.; Morisseau, C.; Yang, J.; Lee, K.S.S.; Huang, J.; Hu, D.Y.; Wu, M.Y.; et al. Epoxide metabolites of arachidonate and docosahexaenoate function conversely in acute kidney injury involved in GSK3beta signaling. Proc. Natl. Acad. Sci. USA 2017, 114, 12608-12613. [CrossRef]

181. Wang, D.; Borrego-Conde, L.J.; Falck, J.R.; Sharma, K.K.; Wilcox, C.S.; Umans, J.G. Contributions of nitric oxide, EDHF, and EETs to endothelium-dependent relaxation in renal afferent arterioles. Kidney Int. 2003, 63, 2187-2193. [CrossRef] [PubMed]

182. Ma, S.K.; Wang, Y.; Chen, J.; Zhang, M.Z.; Harris, R.C.; Chen, J.K. Overexpression of G-protein-coupled receptor 40 enhances the mitogenic response to epoxyeicosatrienoic acids. PLoS ONE 2015, 10, e0113130. [CrossRef] [PubMed] 
183. Pomposiello, S.I.; Quilley, J.; Carroll, M.A.; Falck, J.R.; McGiff, J.C. 5,6-epoxyeicosatrienoic acid mediates the enhanced renal vasodilation to arachidonic acid in the SHR. Hypertension 2003, 42, 548-554. [CrossRef] [PubMed]

184. Cheng, M.K.; Doumad, A.B.; Jiang, H.; Falck, J.R.; McGiff, J.C.; Carroll, M.A. Epoxyeicosatrienoic acids mediate adenosine-induced vasodilation in rat preglomerular microvessels (PGMV) via A2A receptors. Br. J. Pharmacol. 2004, 141, 441-448. [CrossRef] [PubMed]

185. Carroll, M.A.; Doumad, A.B.; Li, J.; Cheng, M.K.; Falck, J.R.; McGiff, J.C. Adenosine2A receptor vasodilation of rat preglomerular microvessels is mediated by EETs that activate the cAMP/PKA pathway. Am. J. Physiol. Ren. Physiol. 2006, 291, F155-F161. [CrossRef] [PubMed]

186. Imig, J.D.; Dimitropoulou, C.; Reddy, D.S.; White, R.E.; Falck, J.R. Afferent arteriolar dilation to 11, 12-EET analogs involves PP2A activity and Ca2+-activated K+ Channels. Microcirculation 2008, 15, 137-150. [CrossRef] [PubMed]

187. Wang, W.H.; Zhang, C.; Lin, D.H.; Wang, L.; Graves, J.P.; Zeldin, D.C.; Capdevila, J.H. Cyp2c44 epoxygenase in the collecting duct is essential for the high $\mathrm{K}+$ intake-induced antihypertensive effect. Am. J. Physiol. Ren. Physiol. 2014, 307, F453-F460. [CrossRef]

188. Sharma, M.; McCarthy, E.T.; Reddy, D.S.; Patel, P.K.; Savin, V.J.; Medhora, M.; Falck, J.R. 8,9-Epoxyeicosatrienoic acid protects the glomerular filtration barrier. Prostaglandins Other Lipid Mediat. 2009, 89, 43-51. [CrossRef]

189. Beck, L.H., Jr.; Fervenza, F.C.; Beck, D.M.; Bonegio, R.G.; Malik, F.A.; Erickson, S.B.; Cosio, F.G.; Cattran, D.C.; Salant, D.J. Rituximab-induced depletion of anti-PLA2R autoantibodies predicts response in membranous nephropathy. J. Am. Soc. Nephrol. 2011, 22, 1543-1550. [CrossRef]

190. Thokhonelidze, I.; Maglakelidze, N.; Sarishvili, N.; Kasradze, T.; Dalakishvili, K. Association of anti-phospholipasea2-receptor antibodies with clinical course of idiopathic membranous nephropathy. Georgian Med News 2015, 49-53.

191. Ramachandran, R.; Hn, H.K.; Kumar, V.; Nada, R.; Yadav, A.K.; Goyal, A.; Kumar, V.; Rathi, M.; Jha, V.; Gupta, K.L.; et al. Tacrolimus combined with corticosteroids versus Modified Ponticelli regimen in treatment of idiopathic membranous nephropathy: Randomized control trial. Nephrology 2016, 21, 139-146. [CrossRef] [PubMed]

192. Wei, S.Y.; Wang, Y.X.; Li, J.S.; Zhao, S.L.; Diao, T.T.; Wang, Y.; Wang, C.; Qin, Y.; Cao, Y.; Wei, Q.; et al. Serum Anti-PLA2R Antibody Predicts Treatment Outcome in Idiopathic Membranous Nephropathy. Am. J. Nephrol. 2016, 43, 129-140. [CrossRef] [PubMed]

193. Bech, A.P.; Hofstra, J.M.; Brenchley, P.E.; Wetzels, J.F. Association of anti-PLA(2)R antibodies with outcomes after immunosuppressive therapy in idiopathic membranous nephropathy. Clin. J. Am. Soc. Nephrol. 2014, 9 , 1386-1392. [CrossRef] [PubMed]

194. Radhakrishnan, J.; Cattran, D.C. The KDIGO practice guideline on glomerulonephritis: Reading between the (guide)lines-application to the individual patient. Kidney Int. 2012, 82, 840-856. [CrossRef] [PubMed]

195. Gonzalo-Gil, E.; Garcia-Herrero, C.; Toldos, O.; Usategui, A.; Criado, G.; Perez-Yague, S.; Barber, D.F.; Pablos, J.L.; Galindo, M. Microthrombotic Renal Vascular Lesions Are Associated to Increased Renal Inflammatory Infiltration in Murine Lupus Nephritis. Front. Immunol. 2018, 9, 1948. [CrossRef] [PubMed]

196. Gerrah, R.; Ehrlich, S.; Tshori, S.; Sahar, G. Beneficial effect of aspirin on renal function in patients with renal insufficiency postcardiac surgery. J. Cardiovasc. Surg. 2004, 45, 545-550.

197. Garg, A.X.; Kurz, A.; Sessler, D.I.; Cuerden, M.; Robinson, A.; Mrkobrada, M.; Parikh, C.R.; Mizera, R.; Jones, P.M.; Tiboni, M.; et al. Perioperative aspirin and clonidine and risk of acute kidney injury: A randomized clinical trial. JAMA 2014, 312, 2254-2264. [CrossRef] [PubMed]

198. De Martino, M.; Chiarugi, A.; Boner, A.; Montini, G.; De' Angelis, G.L. Working towards an Appropriate Use of Ibuprofen in Children: An Evidence-Based Appraisal. Drugs 2017, 77, 1295-1311. [CrossRef]

199. Lipman, G.S.; Shea, K.; Christensen, M.; Phillips, C.; Burns, P.; Higbee, R.; Koskenoja, V.; Eifling, K.; Krabak, B.J. Ibuprofen versus placebo effect on acute kidney injury in ultramarathons: A randomised controlled trial. Emerg. Med. J. 2017, 34, 637-642. [CrossRef] [PubMed]

200. Kaojarern, S.; Chennavasin, P.; Anderson, S.; Brater, D.C. Nephron site of effect of nonsteroidal anti-inflammatory drugs on solute excretion in humans. Am. J. Physiol. 1983, 244, F134-F139. [CrossRef] 
201. Wu, Y.J.; Xue, M.; Chen, H. Licofelone inhibits interleukin-18-induced pro-inflammatory cytokine release and cellular proliferation in human mesangial cells. Basic Clin. Pharmacol. Toxicol. 2012, 111, 166-172. [CrossRef] [PubMed]

202. Faulkner, J.; Pye, C.; Al-Shabrawey, M.; Elmarakby, A.A. Inhibition of 12/15-Lipoxygenase Reduces Renal Inflammation and Injury in Streptozotocin-Induced Diabetic Mice. J. Diabetes Metab. 2015, 6. [CrossRef]

203. Hofstra, J.M.; Beck, L.H., Jr.; Beck, D.M.; Wetzels, J.F.; Salant, D.J. Anti-phospholipase A(2) receptor antibodies correlate with clinical status in idiopathic membranous nephropathy. Clin. J. Am. Soc. Nephrol. 2011, 6, 1286-1291. [CrossRef] [PubMed]

204. Debiec, H.; Ronco, P. PLA2R autoantibodies and PLA2R glomerular deposits in membranous nephropathy. N. Engl. J. Med. 2011, 364, 689-690. [CrossRef] [PubMed]

205. Pourcine, F.; Dahan, K.; Mihout, F.; Cachanado, M.; Brocheriou, I.; Debiec, H.; Ronco, P. Prognostic value of PLA2R autoimmunity detected by measurement of anti-PLA2R antibodies combined with detection of PLA2R antigen in membranous nephropathy: A single-centre study over 14 years. PLoS ONE 2017, 12, e0173201. [CrossRef] [PubMed]

206. Jullien, P.; Seitz Polski, B.; Maillard, N.; Thibaudin, D.; Laurent, B.; Ollier, E.; Alamartine, E.; Lambeau, G.; Mariat, C. Anti-phospholipase A2 receptor antibody levels at diagnosis predicts spontaneous remission of idiopathic membranous nephropathy. Clin. Kidney J. 2017, 10, 209-214. [CrossRef] [PubMed]

207. Buysen, J.G.; Houthoff, H.J.; Krediet, R.T.; Arisz, L. Acute interstitial nephritis: A clinical and morphological study in 27 patients. Nephrol. Dial. Transplant. 1990, 5, 94-99. [CrossRef] [PubMed]

208. Eddy, A.A. Drug-induced tubulointerstitial nephritis: Hypersensitivity and necroinflammatory pathways. Pediatric Nephrol. 2019, 1-8. [CrossRef] [PubMed]

209. Di Rosa, M.; Giroud, J.P.; Willoughby, D.A. Studies on the mediators of the acute inflammatory response induced in rats in different sites by carrageenan and turpentine. J. Pathol. 1971, 104, 15-29. [CrossRef] [PubMed]

210. De Gaetano, G.; Bucchi, F.; Gambino, M.C.; Cerletti, C. Does oral aspirin spare the kidney? Lancet 1986, 1, 736. [CrossRef]

211. Berger, J.S.; Brown, D.L.; Becker, R.C. Low-dose aspirin in patients with stable cardiovascular disease: A meta-analysis. Am. J. Med. 2008, 121, 43-49. [CrossRef] [PubMed]

212. Antithrombotic Trialists, C.; Baigent, C.; Blackwell, L.; Collins, R.; Emberson, J.; Godwin, J.; Peto, R.; Buring, J.; Hennekens, C.; Kearney, P.; et al. Aspirin in the primary and secondary prevention of vascular disease: Collaborative meta-analysis of individual participant data from randomised trials. Lancet 2009, 373, 1849-1860. [CrossRef]

213. Vandvik, P.O.; Lincoff, A.M.; Gore, J.M.; Gutterman, D.D.; Sonnenberg, F.A.; Alonso-Coello, P.; Akl, E.A.; Lansberg, M.G.; Guyatt, G.H.; Spencer, F.A. Primary and secondary prevention of cardiovascular disease: Antithrombotic Therapy and Prevention of Thrombosis, 9th ed: American College of Chest Physicians Evidence-Based Clinical Practice Guidelines. Chest 2012, 141, e637S-e668S. [CrossRef] [PubMed]

214. Karzai, W.; Priebe, H.J. Aspirin and mortality from coronary bypass surgery. N. Engl. J. Med. 2003, 348, 1057-1059. [PubMed]

215. Ali, H.; Shaaban, A.; Murtaza, A.; Howell, L.E.; Ahmed, A. Effect of Long-Term, Low-Dose Aspirin Therapy on Renal Graft Function. Exp. Clin. Transplant. 2017, 15, 400-404. [CrossRef] [PubMed]

216. Rainsford, K.D. Ibuprofen: Pharmacology, efficacy and safety. Inflammopharmacology 2009, 17, $275-342$. [CrossRef] [PubMed]

217. Van Overmeire, B.; Allegaert, K.; Casaer, A.; Debauche, C.; Decaluwe, W.; Jespers, A.; Weyler, J.; Harrewijn, I.; Langhendries, J.P. Prophylactic ibuprofen in premature infants: A multicentre, randomised, double-blind, placebo-controlled trial. Lancet 2004, 364, 1945-1949. [CrossRef]

218. Haas, M.; Spargo, B.H.; Wit, E.J.; Meehan, S.M. Etiologies and outcome of acute renal insufficiency in older adults: A renal biopsy study of 259 cases. Am. J. Kidney Dis. 2000, 35, 433-447. [CrossRef]

219. Martinez Lopez, A.B.; Alvarez Blanco, O.; De Pablos, A.L.; San-Jose, M.D.M.; De La Blanca, A.R.S. Ibuprofen-induced acute interstitial nephritis in the paediatric population. Nefrologia 2016, 36, 69-71. [CrossRef]

220. Steinhauslin, F.; Munafo, A.; Buclin, T.; Macciocchi, A.; Biollaz, J. Renal effects of nimesulide in furosemide-treated subjects. Drugs 1993, 46 (Suppl. 1), 257-262. [CrossRef] 
221. Warrington, S.J.; Ravic, M.; Dawnay, A. Renal and general tolerability of repeated doses of nimesulide in normal subjects. Drugs 1993, 46 (Suppl. 1), 263-269. [CrossRef]

222. Ceserani, R.; Casciarri, I.; Cavalletti, E.; Cazzulani, P. Action of Nimesulide on Rat Gastric Prostaglandins and Renal Function. Drug Investig. 1991, 3, 14-21. [CrossRef]

223. Forget, P.; Machiels, J.P.; Coulie, P.G.; Berliere, M.; Poncelet, A.J.; Tombal, B.; Stainier, A.; Legrand, C.; Canon, J.L.; Kremer, Y.; et al. Neutrophil: Lymphocyte ratio and intraoperative use of ketorolac or diclofenac are prognostic factors in different cohorts of patients undergoing breast, lung, and kidney cancer surgery. Ann. Surg. Oncol. 2013, 20 (Suppl. 3), S650-S660. [CrossRef]

224. Yakar, I.; Melamed, R.; Shakhar, G.; Shakhar, K.; Rosenne, E.; Abudarham, N.; Page, G.G.; Ben-Eliyahu, S. Prostaglandin e(2) suppresses NK activity in vivo and promotes postoperative tumor metastasis in rats. Ann. Surg. Oncol. 2003, 10, 469-479. [CrossRef] [PubMed]

225. Ostrand-Rosenberg, S.; Sinha, P. Myeloid-derived suppressor cells: Linking inflammation and cancer. J. Immunol. 2009, 182, 4499-4506. [CrossRef] [PubMed]

226. Bombardier, C.; Laine, L.; Reicin, A.; Shapiro, D.; Burgos-Vargas, R.; Davis, B.; Day, R.; Ferraz, M.B.; Hawkey, C.J.; Hochberg, M.C.; et al. Comparison of upper gastrointestinal toxicity of rofecoxib and naproxen in patients with rheumatoid arthritis. VIGOR Study Group. N. Engl. J. Med. 2000, 343, 1520-1528. [CrossRef]

227. Ungprasert, P.; Cheungpasitporn, W.; Crowson, C.S.; Matteson, E.L. Individual non-steroidal anti-inflammatory drugs and risk of acute kidney injury: A systematic review and meta-analysis of observational studies. Eur. J. Intern. Med. 2015, 26, 285-291. [CrossRef] [PubMed]

228. Colebatch, A.N.; Marks, J.L.; van der Heijde, D.M.; Edwards, C.J. Safety of nonsteroidal antiinflammatory drugs and/or paracetamol in people receiving methotrexate for inflammatory arthritis: A Cochrane systematic review. J. Rheumatol. Suppl. 2012, 90, 62-73. [CrossRef] [PubMed]

229. Nawaz, F.A.; Larsen, C.P.; Troxell, M.L. Membranous nephropathy and nonsteroidal anti-inflammatory agents. Am. J. Kidney Dis. 2013, 62, 1012-1017. [CrossRef] [PubMed]

230. Catella-Lawson, F.; McAdam, B.; Morrison, B.W.; Kapoor, S.; Kujubu, D.; Antes, L.; Lasseter, K.C.; Quan, H.; Gertz, B.J.; FitzGerald, G.A. Effects of specific inhibition of cyclooxygenase-2 on sodium balance, hemodynamics, and vasoactive eicosanoids. J. Pharmacol. Exp. Ther. 1999, 289, 735-741. [PubMed]

231. Takahashi, K.; Patel, A.K.; Nagai, S.; Safwan, M.; Putchakayala, K.G.; Kane, W.J.; Malinzak, L.E.; Denny, J.E.; Yoshida, A.; Kim, D.Y. Perioperative Ketorolac Use: A Potential Risk Factor for Renal Dysfunction After Live-Donor Nephrectomy. Ann. Transplant. 2017, 22, 563-569. [CrossRef] [PubMed]

232. Griffin, M.R. High-dose non-steroidal anti-inflammatories: Painful choices. Lancet 2013, 382, 746-748. [CrossRef]

233. Zhang, J.; Ding, E.L.; Song, Y. Adverse effects of cyclooxygenase 2 inhibitors on renal and arrhythmia events: Meta-analysis of randomized trials. JAMA 2006, 296, 1619-1632. [CrossRef] [PubMed]

234. Gounaris, E.; Heiferman, M.J.; Heiferman, J.R.; Shrivastav, M.; Vitello, D.; Blatner, N.R.; Knab, L.M.; Phillips, J.D.; Cheon, E.C.; Grippo, P.J.; et al. Zileuton, 5-lipoxygenase inhibitor, acts as a chemopreventive agent in intestinal polyposis, by modulating polyp and systemic inflammation. PLoS ONE 2015, 10, e0121402. [CrossRef] [PubMed]

235. Santos, C.M.M.; Ribeiro, D.; Silva, A.M.S.; Fernandes, E. 2,3-Diarylxanthones as Potential Inhibitors of Arachidonic Acid Metabolic Pathways. Inflammation 2017, 40, 956-964. [CrossRef] [PubMed]

236. Muller, D.N.; Theuer, J.; Shagdarsuren, E.; Kaergel, E.; Honeck, H.; Park, J.K.; Markovic, M.; Barbosa-Sicard, E.; Dechend, R.; Wellner, M.; et al. A peroxisome proliferator-activated receptor-alpha activator induces renal CYP2C23 activity and protects from angiotensin II-induced renal injury. Am. J. Pathol. 2004, 164, 521-532. [CrossRef]

237. Gai, Z.; Visentin, M.; Gui, T.; Zhao, L.; Thasler, W.E.; Hausler, S.; Hartling, I.; Cremonesi, A.; Hiller, C.; Kullak-Ublick, G.A. Effects of Farnesoid X Receptor Activation on Arachidonic Acid Metabolism, NF-kB Signaling, and Hepatic Inflammation. Mol. Pharmacol. 2018, 94, 802-811. [CrossRef]

238. Shlipak, M.G.; Fried, L.F.; Cushman, M.; Manolio, T.A.; Peterson, D.; Stehman-Breen, C.; Bleyer, A.; Newman, A.; Siscovick, D.; Psaty, B. Cardiovascular mortality risk in chronic kidney disease: Comparison of traditional and novel risk factors. JAMA 2005, 293, 1737-1745. [CrossRef]

239. Muntner, P.; He, J.; Astor, B.C.; Folsom, A.R.; Coresh, J. Traditional and nontraditional risk factors predict coronary heart disease in chronic kidney disease: Results from the atherosclerosis risk in communities study. J. Am. Soc. Nephrol. 2005, 16, 529-538. [CrossRef] 
240. Garg, A.; Grundy, S.M. Management of dyslipidemia in NIDDM. Diabetes Care 1990, 13, 153-169. [CrossRef]

241. Garg, A.; Grundy, S.M. Gemfibrozil alone and in combination with lovastatin for treatment of hypertriglyceridemia in NIDDM. Diabetes 1989, 38, 364-372. [CrossRef] [PubMed]

242. Siavash, M.; Amini, M. Vitamin C may have similar beneficial effects to Gemfibrozil on serum high-density lipoprotein-cholesterol in type 2 diabetic patients. J. Res. Pharm. Pract. 2014, 3, 77-82. [CrossRef] [PubMed]

243. Martin-Navarro, J.A.; Petkov-Stoyanov, V.; Gutierrez-Sanchez, M.J.; Pedraza-Cezon, L. Acute renal failure secondary to interstitial acute nephritis and Fanconi syndrome for metamizole and gemfibrozil. Nefrologia 2016, 36, 321-323. [CrossRef] [PubMed]

244. Khan, M.A.; Liu, J.; Kumar, G.; Skapek, S.X.; Falck, J.R.; Imig, J.D. Novel orally active epoxyeicosatrienoic acid (EET) analogs attenuate cisplatin nephrotoxicity. FASEB J. 2013, 27, 2946-2956. [CrossRef] [PubMed]

245. Node, K.; Huo, Y.; Ruan, X.; Yang, B.; Spiecker, M.; Ley, K.; Zeldin, D.C.; Liao, J.K. Anti-inflammatory properties of cytochrome P450 epoxygenase-derived eicosanoids. Science 1999, 285, 1276-1279. [CrossRef] [PubMed]

246. Farzamikia, N.; Sakhinia, E.; Afrasiabirad, A. Pharmacogenetics-Based Warfarin Dosing in Patients with Cardiac Valve Replacement: The Effects of CYP2C9 and VKORC1 Gene Polymorphisms. Lab. Med. 2017, 49, 25-34. [CrossRef]

247. Pei, L.; Tian, X.; Long, Y.; Nan, W.; Jia, M.; Qiao, R.; Zhang, J. Establishment of a Han Chinese-specific pharmacogenetic-guided warfarin dosing algorithm. Medicine 2018, 97, e12178. [CrossRef]

248. Spatzenegger, M.; Jaeger, W. Clinical importance of hepatic cytochrome P450 in drug metabolism. Drug Metab. Rev. 1995, 27, 397-417. [CrossRef]

249. Yanagita, M. Gas6, warfarin, and kidney diseases. Clin. Exp. Nephrol. 2004, 8, 304-309. [CrossRef]

250. Zeldin, D.C.; Wei, S.; Falck, J.R.; Hammock, B.D.; Snapper, J.R.; Capdevila, J.H. Metabolism of epoxyeicosatrienoic acids by cytosolic epoxide hydrolase: Substrate structural determinants of asymmetric catalysis. Arch. Biochem. Biophys. 1995, 316, 443-451. [CrossRef]

251. Imig, J.D.; Hammock, B.D. Soluble epoxide hydrolase as a therapeutic target for cardiovascular diseases. Nat. Rev. Drug Discov. 2009, 8, 794-805. [CrossRef] [PubMed]

252. Shen, H.C.; Hammock, B.D. Discovery of inhibitors of soluble epoxide hydrolase: A target with multiple potential therapeutic indications. J. Med. Chem. 2012, 55, 1789-1808. [CrossRef] [PubMed] 